Portland State University

PDXScholar

\title{
Escalating Language at Traffic Stops: Two Case Studies
}

Jamalieh Haley

Portland State University

Follow this and additional works at: https://pdxscholar.library.pdx.edu/open_access_etds

Part of the African American Studies Commons, Applied Linguistics Commons, and the Law Commons

Let us know how access to this document benefits you.

\section{Recommended Citation}

Haley, Jamalieh, "Escalating Language at Traffic Stops: Two Case Studies" (2017). Dissertations and Theses. Paper 3887.

https://doi.org/10.15760/etd.5775

This Thesis is brought to you for free and open access. It has been accepted for inclusion in Dissertations and Theses by an authorized administrator of PDXScholar. Please contact us if we can make this document more accessible: pdxscholar@pdx.edu. 
Escalating Language at Traffic Stops: Two Case Studies

by

Jamalieh Haley

A thesis submitted in partial fulfillment of the requirements for the degree of

\author{
Master of Arts \\ in \\ Teaching English to Speakers of Other Languages
}

Thesis Committee:

Keith Walters, Chair

Tetyana Sydorenko

Alissa Hartig

Portland State University

2017 


\begin{abstract}
In recent years, the public has seen a rise in recorded footage of violent encounters between police and Black American citizens, partially due to technology such as cell phones, dash-cameras, and body-cameras. This linguistic study examines how these encounters get escalated to the point of violence by asking 1) what kind of directives were used, 2) how were they responded to, 3) how the directives contributed to escalation, and 4) how might power and authority have played a role. I use two case studies to analyze directives and their responses. Findings reveal that repetition of directives on the part of the officers, as well as the rejections to those directives on the part of the motorists tend to aggravate the conversation. I conclude that a variety of directives may represent a variety of reasons the officer might have for a motorist to comply with their directives and that police authority might be better understood and agreed to by the motorist if a variety of linguistic resources were used.
\end{abstract}


Table of Contents

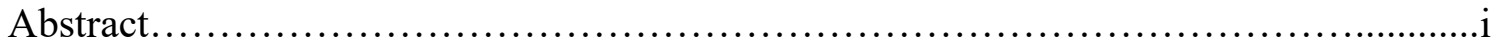

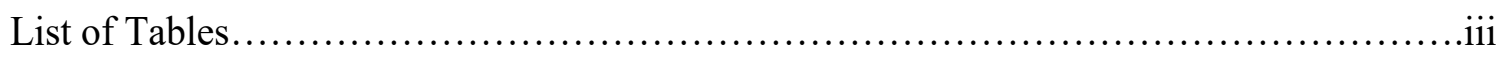

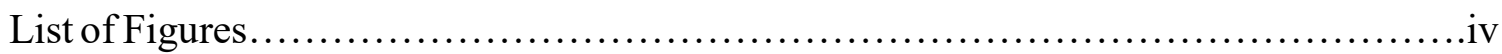

Chapter 1

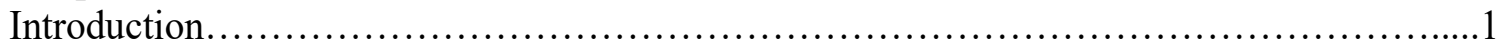

Chapter 2

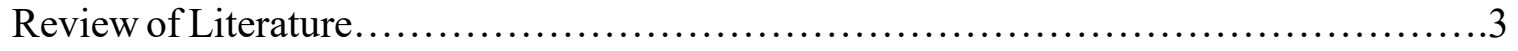

Chapter 3

Design and Methods....................................................... 18

Chapter 4

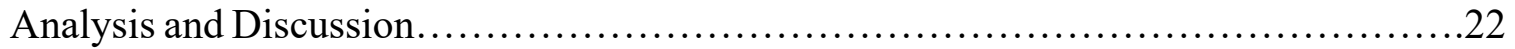

Chapter 5

Conclusion............................................................49

References............................................................... 55

\section{Appendices}

A. Tables with Examples....................................................60

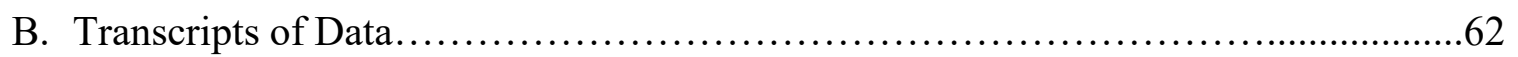




\section{List of Tables}

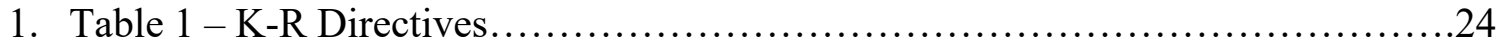

2. Table 2 - B-E Directives............................................... 40 


\section{List of Figures}

1. Figure 1 - Number of directives by Richter per type across response

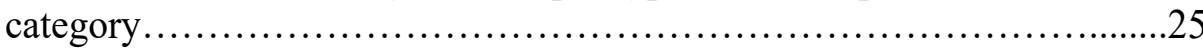

2. Figure 2 - Number of directives by Encinia per type across response

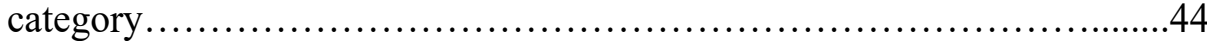




\section{Chapter 1}

\section{Introduction}

This thesis builds on Haley (2016), a pilot study, by examining the speech acts involved in what should have been two routine traffic stops that escalated to violence. Because of racial differences between the police officers, neither of whom was Black, and the drivers, both of whom were Black American women, and because of the violent outcomes, these incidents became part of a larger societal debate about police treatment of Black Americans at traffic stops, implicating both race and gender in their interactions.

I investigate disagreement patterns and characteristics of those patterns in the interactions between the police officers and citizens they stop in my data. Specifically, I look at speech acts to help uncover the directives as a major category of communicative illocutionary acts used by either the police officer, the citizen, or both. Further, my analysis examines what types of directives were used, whether there is evidence the hearer understood the directive as intended, and how those types of directives were responded to. I build on this analysis by exploring the sociolinguistic implications embedded within these interactions, particularly the dynamics of power and authority between police and African Americans. Ultimately, I seek to discover how language likely contributed to the escalations that led to the violent outcomes in the encounters looked at in this study. The paper will seek to address the following questions:

- Was there a particular class of directive (Bach, 1998) that was used more frequently than others in these traffic stops, and what is the patterning of those classes?

- Were the directives understood and accepted as such by the hearer? If so, 
how?

- How did the directives used likely contribute to the escalation of these interactions into violence?

- Were the directives used reflective of the situational and institutional power at work in these encounters, and how did that power likely contribute to how the encounter unfolded?

To achieve these goals, first I review the broader context of the data and research on traffic stop settings, speech acts, and the ways power and authority interact with each. In the methods section, I then discuss how I will use the tools from speech act theory and discourse analysis to analyze these incidents, again building on Haley (2016). My analysis reviews the two cases, one by one, and then discusses the implications of power and how the results of this study might be used. The final section of the thesis draws conclusions and discusses some implications of the analysis. 


\section{Chapter 2}

\section{Review of the Literature}

This chapter has two functions: to explore the social context in which the data occur and to explore the research that supports the analysis.

\section{The Broader Context}

Recently, violent encounters between police and Black Americans have drawn the pointed attention of the media in the United States. Particularly, encounters during traffic stops seem to be salient examples of racialized violence many Americans are concerned about. Here, I explore some of the background of racial prejudice and how it is connected to policing.

Events such as the ones in my data must not be looked at in isolation from the broader context of the civic disenfranchisement of Black Americans or the history of the civil rights movement in the US. Many Black Americans feel they are denied full citizenship and freedom in their own country, fueled partially by the fraught relationship between the Black community and law enforcement and the criminal justice system. Perhaps part of the public response to encounters such as the ones in my data asks why disproportionate numbers of traffic stops continue to involve a particular racial group, Black Americans; that is, since Black Americans say they feel targeted, is it likely that their responses while being stopped reflect that burden?

The social context of racialized violence might help to shed some light on what kind of language is used in these interactions and how that language reflects the deep feelings involved. Particularly, the recent social movement Black Lives Matter has heightened awareness around racial injustice. With the movement has come more public 
expressions of deep dissatisfaction from both the black community, who feels targeted by police, and their supporters, on the one hand, and critics, who label the movement as antipolice, on the other. This dynamic has begun to stir up anger and action from Americans on all sides of this issue, while events such as the ones in these data demonstrate that a very real contention exists between police and motorists in this particular setting and under the authority of policing.

My analysis will focus on two separate encounters, each documented by dashcamera and made public by the police. One such video documents the traffic stop that led to Sandra Bland's arrest in July 2015 in Waller County, Texas. Ms. Bland made efforts to protect herself, but also efforts of protest and resistance. Her arresting officer, Brian Encinia, showed efforts to invoke both his institutional and perhaps personal authority and to compel Bland to comply with that authority. The second encounter I look at involves school teacher Breaion King and an officer in the city of Austin, Texas in July 2015; this encounter quickly became violent after the officer stopped King for speeding while on her lunch break. King was pulled from her vehicle and flipped onto the pavement after she would not put both her feet in her car.

In the following sub-sections, I build an argument about the nature of power structures and authority by discussing traffic stop settings as well as speech acts.

\section{Traffic Stop Settings}

Traffic stop settings are unique both in social and institutional context and in research. Much research has been published in the forensic field as to Fourth Amendment rights and Terry searches at traffic stop settings, as well as to the expected nature of traffic stops (LaFave, 2004; Lawrence, 2004). (The Fourth Amendment guards against citizens 
being searched unreasonably while a Terry search is one in which the Supreme Court holds that if police have reasonable suspicion that a person stopped is about to be engaged in criminal activity, they may detain and search a motorist.) Traffic stop interactions generally follow a routine; for the officer, the language used is commonly an institutional action that includes a series of directives: asking for a license, asking where the motorist is coming from and going to, questioning about identities, as well as directing future action. This routine also usually involves criminal history and outstanding warrants checks (LaFave, 2004). For the motorist, the routine usually involves answering the officer's questions and providing relevant information, including accounts of their activity. When the routine is interrupted or goes off course, both the officer and the motorist may need to improvise the language they use. Lawrence (2004) asserted that when issues during routine traffic stops arise, it is often correlated with the officer asking questions that are unrelated to the stated original reason for the stop.

Traffic stops hold potential danger for both police and citizens. In response to the potential danger to police, the United States Supreme Court has reinforced police institutional authority in cases such as Whren v. U.S. (1996), which allows for more individual agency in policing. Such agency is seen to play out in actions such as searches, removals from vehicles, and use of force (as seen in the data in this paper). All these elements have contributed to social contention about the traffic stop setting, necessarily heightening anxiety around potential encounters for both parties. In addition to concern for police safety at traffic stops are growing public perceptions of police as violent or abusive of their power (Capehart, 2015; Whitehead, 2015), racial profiling before and during stops (Epp, 2014), and the salience of media coverage of violent encounters 
between police and Black American motorists.

In linguistic research on police-citizen interactions, studies have centered mostly on interrogation or question settings or responses to 911 calls (Ainsworth, 2008; Mason, 2016; Stygall, 2008). Many of these studies have focused on coercion, problematic talk, or interrogative speech acts and found that power and register play a large role in how police communicate with citizens, particularly in bilingual settings (Berk-Seligson, 2009).

Given the limited existing linguistic research on police-citizen interactions at traffic stops, it is necessary to narrow the focus of these interactions beyond what the research has already addressed; traffic stop settings are unique in their tenuous dynamics of police authority in combination with motorists theoretically having some agency. Contrasted with citizens brought in for questioning, interrogated in connection with serious crimes, or having called for help, motorists at traffic stops usually remain in their vehicles and are often culpable of only minor infractions, such as failing to signal or missing a tail light. While the context seems to beg for an analysis rooted in sociology, the studies mentioned above compel linguistic questions and show that police-citizen interactions manifest themselves in and through talk. Thus, in addition to insights from other disciplines, understanding the traffic stop setting requires a linguistic approach to potentially understand how interactions can unfold so dramatically.

\section{Power in Traffic Stop Settings}

In this section, I explore how existing research has yet to focus on power through language between officers and motorists at traffic stops. Many sociology and criminology studies have focused on traffic stops to investigate police leniency (Farrell, 2015), police and driver demeanor (Engle et al., 2012), gender bias (Blalock, 2011), and racial profiling 
(Carroll et al., 2014; Childers, 2012; Rojeck, 2012). In slightly broader legal settings, escalation has been investigated through a linguistic lens: Matoesian (2005) argued that the unfolding of control and resistance talk in trial settings yields identity contextualizing, where identity is manipulated through discursive practice; "human agency is fundamental to any negotiation of power and social interaction" (Smith, 2010, p. 173). Such research likely hold implications for police language and traffic discourse.

Smith (2010) built upon Matoesian's claim, but concluded that talk reflects power in contextualized settings. For instance, at a traffic stop, the talk is expected to uniquely reflect the power dynamic of that context, and such talk will not likely be used outside of that context. According to Smith, settings like this one are contextualized through identity locally (at the time of interaction, and not before), and are not static. Traffic stops might also change in relation to forces outside of the context. In other words, participants bring identities into the traffic stop setting that possibly change the nature of that setting. A relevant example might be what some contend is Black Americans' increasing willingness to speak up and assert their rights at traffic stops, possibly spurred by the advent of the Black Lives Matter movement. In this example, a social force changes how participants might identify during a stop; the motorist might identify as a person with agency who has the right to ask questions and question authority, or she might identify as someone who is oppressed and under attack.

Despite the common notion that the officer has the power to question and direct while the motorist does not have such power, the dynamic of the traffic stop does not necessarily preclude agency on the part of the less powerful, where "agency" is the capacity to act in the situation. In this scenario, the police officer fills the role of 
"institutional authority," where the institution is "government" either on a local or state level. Thus, traffic police possess given or endorsed agency; at issue is the agency of the motorist. Smith and Guthrie's conversation analysis of police-citizen traffic interactions (in Smith, 2010) showed that both parties' talk evoked the institutional authority of police and that turn-by-turn, both parties agreed to the institutional role and thus showed agency on the part of the less powerful party. For example, Smith and Guthrie argued that latching speech (near overlapping) and offering accounts constituted evidence that both parties negotiated institutional authority. Their analysis of contextualized talk demonstrated that 1) traffic police represent institutional authority and 2) motorists who have been stopped can in some cases enact agency by negotiating an agreement with that authority. However, their study also emphasized the limited control motorists have over the outcome of their situations. The present study will seek to determine whether the motorists in the two videos analyzed negotiated this power dynamic of authority and what kind of linguistic options they had to exercise the rights they perceived themselves to have.

When power is introduced into a local setting, the contextualizing of identities by the participants might be expected to occur through resistance or the testing of that power. It is possible that a motorist revealing "stance" is a mode of contextualizing — aligning oneself in relation to the other person. Goffman (1981) argued that a participant's stance reveals or becomes an issue in the talk, either explicitly or implicitly, and represents a "shift in footing." Smith (2010) concluded that through such "shifts in footing" (p. 176), motorists commonly resist the institutional representative, that is, the officer, by asserting agency in the form of offering explanations and accounts for their behavior; these 
accounts contrast with the narrative given by the officer for their stop. While Smith's study offered analysis of these contextualizing negotiations around power at traffic stops, her study did not include overt or direct assertions of opposition between these two parties. In light of these findings, the data in this current study raise a number of issues: How far can Matoesian's concept of resistance-talk go? How do traffic stop encounters unfold when the motorist expresses direct resistance to traffic police? What happens when the officer and motorist do not settle on an agreement with regards to the institutional power traffic police have, as per Smith and Guthrie's concept of negotiation (1996)? And what greater contexts contribute to the asserting of agency and the resistance to institutional power?

\section{The Particular Status of Directives}

In order to think more deeply about the above questions, I will examine linguistic features that occur in the traffic stop setting; of particular interest in traffic stops is the speech act category of directives. Speech acts are distinguished by their illocutionary class, as set up by Searle (1976). Distinguishing one illocutionary type from another helps to understand the difference in force between utterances; in regards to the data analyzed in this paper, distinguishing types may make it possible to determine whether and how a speech act was understood or not. Bach and Harnish (Bach, 1998) adapted Searle's framework, and they distinguished his classes of directives as advising, admonishing, asking, begging, dismissing, excusing, forbidding, instructing, ordering, permitting, requesting, requiring, suggesting, urging, and warning.

\section{Directives, perlocution, and responses.}

The purpose of a directive is, as Searle (1976) pointed out, usually an attempt to 
get the hearer to act in some way, or, alternatively, as Dorschel (1989) described, to get the hearer to ascribe to some value, attitude, or belief that may or may not trigger an action. In the data analyzed in this thesis, the officers gave directives that implied they wanted the motorists to believe in or value the formers' positions of institutional authority over the motorists. According to Dorschel, the conditions of satisfaction for the speaker is that the action requested is fulfilled by the hearer. In other words, the hearer does not have to actually share the beliefs or values the directive implies, but only act as if they do.

In his philosophical paper about the conditions of fulfillment of directives, Dorschel, perhaps unconventionally, applied a semantic argument about truth conditions for the reasons represented by the directives but the not truth conditions for the directives themselves. His theory differentiated between truth conditions and felicity conditions by focusing how reasons the speaker would expect the hearer to fulfill a directive are given rather than focusing on the contextual truths of the directive. One deals with intention (reasons) while the other deals with contextual conditions (felicity), even though one might or might not rely upon the other. "Truth conditions" is perhaps a misnomer-the term as Dorschel used it is taken from semantics, or meaning, and creates a form of analysis that can accommodate intention by treating the directive (or action) as representing reasons the speaker might feel justified in their utterance.

Dorschel built upon Grice's (2001) foundation of reasons: if directive speech acts reflect the conversational background or situation in which they occur, they act as practical reasons for the hearer to act, at least from the speaker's perspective. For example, if A has a gun visible to B and says, "Get on the floor," the gun acts as a practical reason for B to comply with the speech act. Because Dorschel focused on 
reasons underlying directives and not the acts themselves, this thesis talks about truth conditions rather than felicity conditions. In my analysis, I use this notion of reasons to help define directives specific to this traffic stop encounter and identify and categorize their correlative responses. Kissine (2013) operationalized this notion as X being the directive speech act of $\mathrm{A}$, and $\mathrm{B}$ being the hearer; the reasons for $\mathrm{B}$ to bring about the truth of X may or may not be enough to cause B to actually bring about the truth of X. Here, $\mathrm{X}$ and the truth of $\mathrm{X}$ are distinguished, and the relationship between $\mathrm{X}$ and the truth of $\mathrm{X}$ is defined as the perlocution.

Dorschel (1989) also argued that a speaker's directive usually claims to have some authority over the hearer that can stand in as reasons. For example, the officers in these data might have used their institutional authority as the reasons for the motorists to fulfill the directives given. Therefore, the relationship between the directive and the bringing about of the truth of the directive can depend on not only the belief in the reasons but also the knowledge of (or at least the willingness to acknowledge) presumed authority, institutional or otherwise. This presumption would give A the right (at least under certain conditions) to issue certain directives and expect to be obeyed. In my data, institutionalized authority was certainly at play and possibly other types of authority, as well.

Dorschel's criteria for understanding a directive are below:

A hearer understands an imperative,

1. if he knows the conditions under which he would bring about the desired state, and

2. if he knows the conditions under which the speaker would have 
convincing reasons to regard an imperative as either

a. valid (that means: normatively justified) or

b. efficient (that means: supported by potential sanctions sufficiently deterring from disobedience) (p. 329).

Dorschel went on to describe how hearers show understanding of a speech act; he categorized hearers' responses to understood directives as accepting them (carrying them out), reserving judgment ("I cannot decide at this moment" or "I may have some questions about that"), or rejecting them (not carrying them out or outright refusing to do so). Dorschel concluded that the reasons the speaker should expect the hearer to perform the action of the directive is a major component of understanding the directive. His classic example is the gunman shouting "Hands up!" wherein the gun might function as a reason for the hearer to comply. Without a gun as a reason, a hearer may reject the directive because there is not reason enough (i.e. "You are not the boss of me" or a moral rejection "I won't be party to this illegal act"). If the person with the gun was a police officer, there might be reasons other than the gun compelling the hearer to obey, such as the officer's institutional authority. In this scenario, it is presumed that the act of obeying demonstrates understanding of the reasons and acceptance that a directive was given.

In general, success of communication is measured qualitatively when the communication has been taken as intended. Since there is inherent difficulty in judging communication as successful or not, it is important to not assume that the directives themselves that are not carried out were misunderstood or not taken as intended. What previous research shows is that a directive can be understood, acknowledged, and not followed; in other words, that a directive is not followed does not necessarily mean the 
directive was not understood. Thus, I will use the aforementioned notions and definitions below to help identify and categorize directive speech act types and their communicative successes.

\section{Threats.}

Threats also play a role in the data analyzed in this study, particularly as they correspond to institutional authority. Shon (2005) defined threats as direct and conditional speech acts with unfavorable consequences for the hearer. He categorized threats and warnings as part of a fraternal order of force. He contended that the police's ability to coerce and use force is always an ever-present factor in the unfolding of an encounter and not merely a precondition to be invoked at chosen times during the encounter. Thus, this potential deployment of coercive force manifests itself in all directive utterances, which include gesture, artifacts, and words: requesting, advising, questioning, warning, and ordering. Shon's argument was that in police-citizen encounters interaction as we usually use the term is mitigated or perhaps non-existent, whereas transaction takes over; that is to say, in traffic stop settings "messages are not 'exchanged' [between two parties] but 'delivered' [from one party to the other]" (p. 830), or in this case, from the officer to the motorist. The difference lies between an interaction that is mutually engaged in as a free exchange and an interaction where one party dictates how the other party should participate. The implications are, then, that any message from an officer might and perhaps should be taken by a stopped motorist as a warning or threat, or at least a potential one. In fact, Fraser (1998) and Storey (1995) argued that a major feature of threat is power or authority over others and that the threatener must believe they have the ability or power to carry the threat out as well as the intention for the threat to be taken as 
such. In his discussion, Fraser defined three conditions that constitute a threat: 1) intention to threaten an action 2) the action must be unfavorable to the hearer, and 3) the intention must be to intimidate. Because intention is a difficult construct to navigate, Dorschel (1989) has argued that a threat must also be mutually understood and that it is usually made for the speaker's benefit (to change the behavior or coerce some action from the hearer (Searle, 1976)). In light of Dorschel's observations, I would argue that in addition to the speaker holding such a belief, the hearer must also believe that the speaker has the power or ability to carry out the action of the threat.

Dorschel used speech act theory to identify participants' understanding and acknowledging of threats. Below, I use speech act theory to look for evidence of threats in the data between police officers and motorists. Based on previous literature discussed in this review, I use four criteria to identify threat-making: 1) institutional power held by the speaker, 2) contextual (local) power and authority held by the speaker, 3) the speaker's ability or power to enact the threat, including the accoutrements to enact the threat, and 4) mutual agreement between the speaker and hearer that the threat was made, with potential unfavorable outcomes for the hearer.

According to Smith (2010), the power dynamic of negotiated authority in traffic stops is implicit in most encounters, but when paired with warnings and threats, negotiating power may produce conflict-talk. This consequence might depend on how the threats are given and taken. While examining how language and context together influence the degree of threat and lawfulness in an utterance, Storey (1995) argued for the difficulty of constructing a context-independent or an identity-independent definition of threat; the definition of threat is always contingent upon the identities that the participants 
bring to the setting. For example, in the greater context of the civil rights movement, the identity of a Black American might play a larger or different role at a traffic stop than that of a white American, and can potentially change the nature of threat. This argument suggests that the power of threat is multi-fold; it originates from multiple sources and presumably has multiple consequences, including how a speaker may choose to threaten and how and when a hearer may respond.

\section{Contributions to Escalation}

The discussion of the literature thus far helps to elucidate how language reflects power dynamics in traffic stop settings and how threat-making serves as an imposing factor that could lead to conflict. Research on language that contributes to escalation of conflict has focused largely on organization and structure (speech acts, rhetorical moves, format tying) and among children (Brenneis \& Lein, 1977; Boggs, 1978; Goodwin \& Goodwin, 1987; Maynard, 1985). In contrast, Grimshaw (1990) and O'Keefe (1977) researched adult disagreements and laid the foundation for constitutive language study on how discourse and conflict might be related. Through their formative research, they divided disagreements into three phases: inciting event, opposition, and reaction.

Scott $(1998,2002)$ described the linguistic features that constitute these phases in face-to-face disagreements between adults; in particular, she looked at how specific linguistic features contribute to the disagreement and sought to discover how these features determine the course and outcome of the disagreement. In her 1998 study, Scott defined two types of disagreements: background and foreground, both located on a continuum of characteristics shared. She argued that background disagreements are marked by long turn-taking, few turns per disagreement, explanatory talk utilizing 
evidence, use of implication and inference, and particularly by lack of explicit disagreement. Scott described these background disagreements as calm and measured. Conversely, foreground disagreements are marked by short and overlapping turn-taking, explicit opposition, and the use of negation, repetition, indexical second-person pronouns, questions, modals, and discourse particles. Her analysis uncovered three categories with regard to foreground disagreements that might be relevant to the proposed study: collegial disagreements, personal challenge disagreements, and personal attack disagreements, which she found formed a "continuum of increasing hostility" (p. iii). I was able to find only very context-specific research on disagreement, such as Lorenzo-Dus's (2008) TV courtroom study, Nissi's (2013) research on Bible study sessions, or Maschler and Nir's (2014) case study of Hebrew discourse. Each of these studies discussed "conflict-talk" and used aspects of Scott's analysis to help identify and index disagreements. Recent research, however, has not furthered Scott's findings generally or specifically, and particularly not in the very specific setting of traffic stops.

When looking at how arguments are constructed, Goodwin (2006) focused on how participants orient to previous utterances in order to organize their following utterances using "format tying." The research showed that participants shape their arguments as they go, dependent upon retrospective and prospective utterances. Participants do this, Goodwin argued, by using language structures that occurred earlier in the conversation. Language structures can include single words, phrases, or even syntactic structure. For example, if one participant says "You have to go," the other participant might say "I don't have to do anything." Orienting to the structure of the first participant, the second participant repeats "have to" as a contested action. Goodwin contends that format tying is 
an explicit marker of countering an opponent. He concluded that in some cases format tying is a way for a participant to negotiate autonomy and might mark changes is social positioning.

Format tying also can involve refusals to respond in sequentially appropriate ways. Since language is mirrored and repeated in format tying, Goodwin found that a consequence might be that questions are not answered and issues are evaded, resulting in directives going unfulfilled. As demonstrated in the data below, the repetition that occurs can fruitfully be analyzed in terms of Goodwin's model of analysis.

Relevant insights from previous research have provided a basic understanding of how linguistic features link discourse to conflict, while more recent research has argued that institutional power is context specific and is often agreed upon (or not) wherein the authority is implicated in threat-making. The research suggests that those threats are everpresent in settings like traffic stops, possibly contributing to conflict-talk that might lead to or even exacerbate violence. Since each of these arguments clearly applies in a traffic stop setting, the analysis below investigates the intricacies that are involved in two encounters that erupt in violence and possibly determine the larger roles language played in such dire outcomes. 


\section{Chapter 3}

\section{Design and Methods}

This study of video recordings of interactions between police and citizens used an exploratory, multiple case-study design to look at escalating language. My analysis was

primarily qualitative. My choice to do a qualitative analysis arose from a desire to clarify some of the confusion and concern by the public and the press around these high-profile interactions, as well as to perhaps lay the foundation for future work that might involve creating appropriate procedures for police officers who might encounter situations like these. In this study, I treat talk between police and citizens as a kind of organizational or institutional talk, likely setting for the parties involved relative expectations of how these encounters should unfold. I use discourse analysis and speech act theory to look at social and institutional aspects present in these data.

\section{Criteria for Data}

For this study I analyzed two segments of conversation between police officers and Black American citizens at traffic stops. The data are video recordings captured by police dash-cameras. All the footage I used has been made public either on YouTube or released through news sites. I chose these encounters because of the nature of the traffic stops, which were minor infractions, and the outcomes of the traffic stop, which were physically aggressive and resulted in arrests during which both parties were injured. My selection was also influenced by the attention the encounters received by the public and press, particularly in Sandra Bland's case after the dash-cam footage was released in response to her death in jail three days after her arrest. The criteria for choosing data included the following: 
1. occurred between a single police officer and an unaccompanied Black American citizen,

2. initiated as a non-violent stop and not a summons or report,

3. led to violence between the officer and citizen, and

4. be recent (within 5 years)

First, I set these criteria based on recent overwhelming public outcry in response to some officers' violent encounters with Black Americans. During my review of the tremendous amount of data that fits the first criterion, I rarely encountered officers of color. In the Sandra Bland case, the officer involved has a Hispanic surname, though it is difficult to tell what his race is or how he identifies racially. I did not encounter data involving a single Black American police officer and a Black American motorist.

Second, much of the public outcry is centered on cases that seem to begin as a routine traffic or sidewalk stop. Part of my criteria were that the stop must be made by onduty officers and for minor violations, such as speeding, broken lights, or failure to signal. I excluded any encounters that began with a call for help or a report either by another officer or a citizen. I chose this criterion to avoid encounters that begin with violence or dangerous activity or encounters where the officer's weapon is already drawn. The dominant presumption by the public is that these stops for minor infractions can and should go smoothly and end without escalation to violence.

Third, I used the World Health Organization's (WHO, 2016) definition of violence as "intentional use of physical force or power, threatened or actual, against oneself, another person, or against a group or community, which either results in or has a high likelihood of resulting in injury, death, psychological harm, mal-development or 
deprivation" (para. 5). Lastly, I used recent data to better address the prevalent anxiety around encounters such as these that have sparked several movements and protests in the recent years.

\section{Analysis Procedures}

Much of my analysis was based on the results from my pilot study (Haley, 2016), which I approached from a Discourse Analysis perspective, and applies the constructs discussed in the literature review. Within this broad framework, I took an exploratory approach. As in my pilot study, my first step was to transcribe the conversations using basic transcription, including pauses in seconds (ex. .5 for five seconds) and noting some overlapped speech with brackets. Since these data contain so many orders and threats, I used speech act theory (Searle, 1976), particularly focusing on directives and then narrowing down to orders and threats. Using the definitions outlined in the literature review, I identified all the directives. Next, I categorized the type of directive being used and coded each one according to Bach and Harnish (1998). Finally, I identified which speech acts were a response to the directives and categorized them according to Dorschel's classes (1989). I used Dorschel's philosophical argument as a foundation to discuss locutionary-illocutionary acts, but focused primarily on perlocution in an attempt to understand those responses given to the threats. I counted the number of directives to highlight their salience and compare between the two encounters. I also examined the extent to which the directives and responses tended to correspond.

The coding process was iterative; how I defined one utterance sometimes changed how I defined the next or the previous utterance. Some coding is multifunctional and poses categorical problems. For example, "get out of the car" is categorized as 
imperative/ordering, but "get out of the car now" complicates the utterance by including the aggravator "now." The difficulty lies in the difference of perception between the speaker and the hearer; of course, participants may perceive illocutionary force in different ways. The guiding factor was what came after the problematic utterance- that is, its uptake. I have assumed that Dorschel's (1989) classes of response provide an objective framework to judge how the utterance was taken.

I frequently encountered ambiguity between instructing and ordering since both types of these utterances often use imperative forms. Haverkate (cited in Martinez-Flor \& Uso-Juan, 2010) suggested that the difference between instructing and ordering lies in the benefits of carrying out the act. The benefits of an order would be exclusively for the speaker whereas the benefits of an instruction would be for the hearer. I made discerning judgments about my data using this definition based on lexical choices, tone, and how utterances were structured. For instance, I coded "Take a seat back in the car so we can close the door" as an instruction but coded "Put your feet back in the car so I can close the door" as an order.

After coding utterances, I looked at which directives conveyed reasons for the speaker to believe their directive would be fulfilled and whether the hearer seemed to share in those beliefs. I applied Dorschel's philosophical analysis and Kissine's formula to aid in my qualitative analysis of the relationship between illocution and perlocution. This process made up the bulk of the analysis. 


\section{Chapter 4}

\section{Analysis and Discussion}

This section will review the data, case by case, first from a quantitative perspective and then from a qualitative one. The quantitative analysis provides a way to see how the directives were distributed between the speakers and also how responses were given in proportion to the directives the speakers used. This quantitative analysis also helped to direct the qualitative discussion and to explore how the coding reveals the nuances of the interaction.

\section{Case 1: King-Richter Data}

The first case involves data from the King-Richter encounter. (See Appendix B, Case Study 1 for transcript.) In June, 2015, Breaion King, a petite 26-year-old Black American woman, was pulling into a Wendy's parking lot in Austin, Texas when police officer Bryan Richter pulled in behind her parked car. As King exited her vehicle, the officer approached her, asked her to get back into her vehicle, and warned that she was being stopped for speeding. According to the officer, King sped past his radar at $50 \mathrm{MPH}$ in a $35 \mathrm{MPH}$ zone. Later, King, an elementary school teacher, claimed she was on her lunch break and turned into the parking lot, unaware she was being pulled over. On the video, the speaking begins with King exiting her vehicle and the officer's approach and caution.

The encounter is relatively brief: King was handcuffed and put in the police vehicle by 2:50. At the beginning of the encounter, officer Richter asked King to get back in her vehicle. King got in her car but did not close the door. After King asked whether she could be given a ticket even though she was parked, and after she produced her 
license, Richter asked King to put her feet in the vehicle so he could close the door. At :55 King responded by asking "Can you hurry up?", and Richter immediately reached into the vehicle and instructed King to exit. With that reach, a physical struggle began, and officer Richter pulled King out of her vehicle, flipping her onto the pavement. Richter struggled to move King's arms behind her back, but King resisted. Richter and King struggled to a standing position, and Richter flipped King onto the pavement again. Several times, the officer called for King to stop struggling and to put her hands behind her back. King cried out in pain several times and repeated that she was trying to comply. Finally, Richter handcuffed King, picked her up by her arms and bent her over the hood of the police vehicle as other officers arrived.

This encounter received considerable media attention both because of the participants' relative size difference and the amount of physical struggle between them, and because of the conversation between a second officer and King in the back of the police vehicle about race during which that second officer claimed that white people are afraid of Black Americans because of the latter's “violent tendencies.” This conversation was seen by many as evidence of racial bias as a predisposition to racial profiling on the part of the police and as having potentially created a racialized context for the first part of the video during which King was arrested. In my investigation of how speech acts might have contributed to the escalation to violence, I do not analyze the second part of the video in which King is in the police vehicle; only the 2 minutes and 50 seconds of interaction between King and Richter are relevant to this study. However, given the larger sociocultural context of this study, acknowledging this later interaction is important. 


\section{Quantitative results.}

What became most apparent immediately about the King-Richter interaction was the sequencing of the officer's speech acts: repetition of instructing that preceded repetition of stating that preceded the repetition of ordering. In the midst of ordering, one threat was made, “I'm gonna Tase you” (line 56), while trying to get King handcuffed. Notable were the 7 repetitions of officer Richter's "Stop resisting!" (lines 26-32) and his 9 repetitions of "Put your hands behind your back!" (lines 42-62), with one amplifier "Now" tagged onto the penultimate order. Of Richter's 37 utterances, 36 were directed at King, and of those 2 were instructing, 3 were requesting, 1 was asking, 23 were ordering, 7 were statements (constatives), and 1 was a performative "You're under arrest" (line 44). Table 1 below shows the total number directives each participant gave divided into directive type. Officer Richter used ordering the most, followed by instructing while King used questioning the most, trailed by ordering.

Table 1 - K-RDirectives

Types of directives used number of times by Richter and King as percentage of total directives in selected text.

\begin{tabular}{l|r|r}
\hline Type & \multicolumn{1}{|l|}{ Richter } & \multicolumn{1}{l}{ King } \\
\hline Ordering & $83 \%(\mathrm{n}=24)$ & $22 \%(\mathrm{n}=5)$ \\
\hline Instructing & $10 \%(\mathrm{n}=3)$ & 0 \\
\hline Warning & $3 \%(\mathrm{n}=1)$ & 0 \\
\hline Requesting & $3 \%(\mathrm{n}=1)$ & 0 \\
\hline Questioning & 0 & $77 \%(\mathrm{n}=17)$ \\
\hline TOTAL & 29 & 22 \\
\hline
\end{tabular}

When looking at King's utterances, I was able to find few accepting speech acts to tally. While most of King's responses were constative speech acts, only 3 might be considered accepting: "I'm getting out" (line 36), “That's what I'm doing” (line 63), and "I'm not trying to stand up" (line 65), all in direct response to ordering. In regards to 
Dorschel's categories of responses as accepting, reserving judgment, or rejecting, King reserved judgment 11 times total, seven times after an order, accepted six times, and rejected eight times. Several of those utterances were secondary utterances to a preceding utterance of a different type (i.e. “That's what I was doing. Are you serious?” (line 63), where the first utterance I coded as accepting and the second I coded as reserving judgment). Below is a chart showing each response type as it corresponds to the type of directive given. The non-response category reflects utterances when King might have been confused or unable to respond. The chart highlights that King did not accept any directive except orders and that all of her rejecting was in response to orders. All three response types were used relatively equally in response to ordering with eight rejections, seven reservations, and six acceptances.

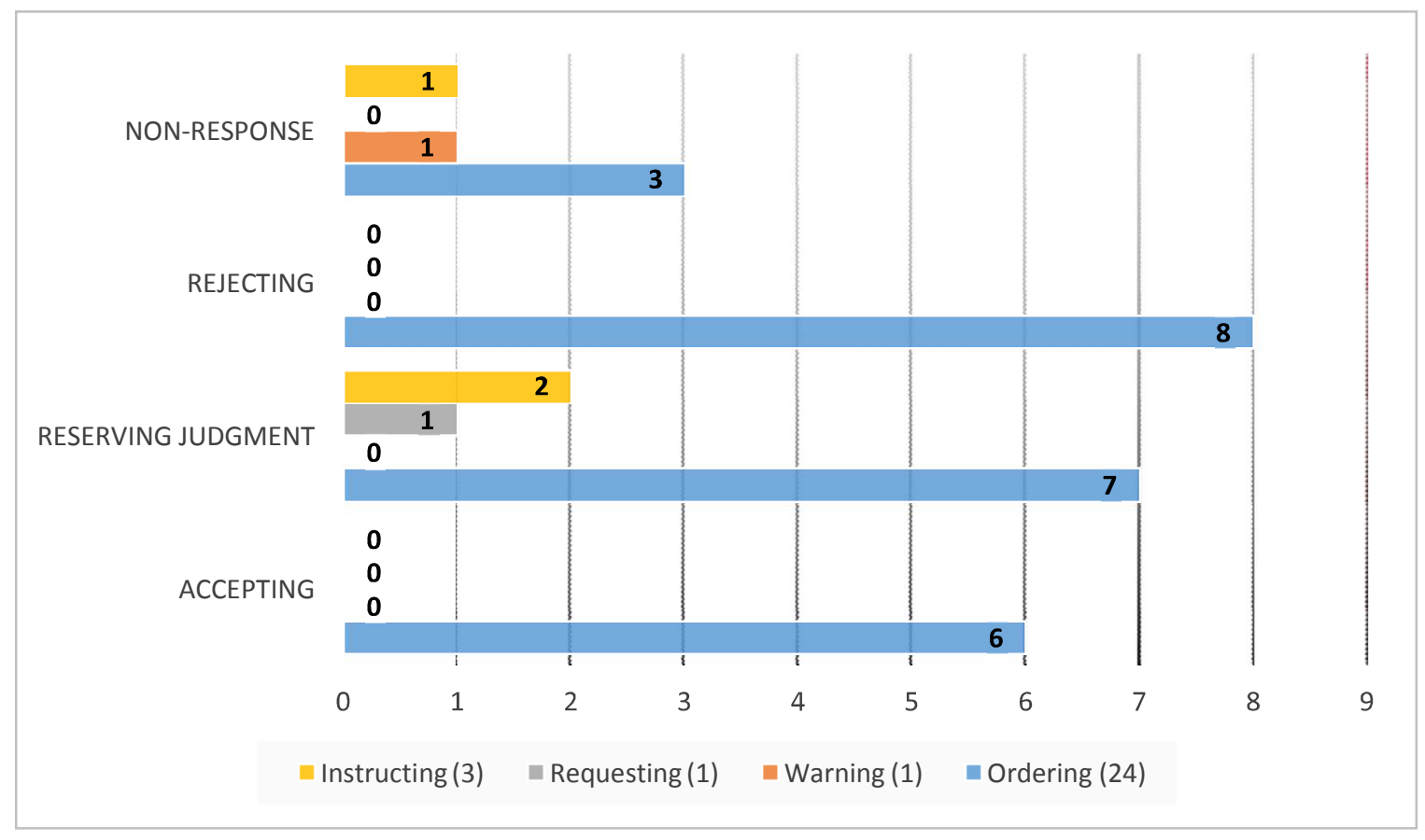

Figure 1: Number of directives by Richter, the officer, per type across response category. Chart includes total number of uses per type of directive by Richter. 
The data in quantitative form provide some bearings to see the proportion of directives used across the two parties. The officer's utterances were far more repetitive than King's and tended to increase in intensity, progressing from one type of directive to the next, whereas King's utterances reflected various directives throughout the interaction. This quantitative analysis helped me to know where to focus my qualitative efforts to further discuss the interaction and explore how the coding makes sense of the interaction given the specific context.

\section{Qualitative discussion.}

Officer Richter began the encounter with King by instructing ("Ma'am take a seat back in the car please" (1)), then moved into asking questions ("Can I see your driver's license?" (9)), followed by making statements ("Ma'am you were about to go inside without a wallet" (14)), and ended by making several orders in a row ("Put your hands behind your back!" (42)), most of them repeated. The sequencing certainly indicates escalation, as do the repetitions. Notable are the 4 repetitions of orders to "Stop resisting" in lines 26-32, followed by the 8 repetitions of the order to "Put your hands behind your back" in lines 42-62. Each order was given with no variation and a sustained intonation of intensity, regardless of the verbal response King gave. What Richter was looking for, presumably, was not a vocal response, but a physical one; it seems he disregarded all vocal responses and remained persistent in his locution.

Richter's high use of directives seems potentially appropriate for a traffic stop, even for one that did not unfold smoothly (cf. LaFave, 2004). The encounter began with varied speech acts, including requesting and instructing, interspersed with constatives. When Richter instructed, King complied: 
5 RIC: Okay ma'am you're being pulled over right now so I need you to take a

6 seat back in your car.

$7 \quad$ KIN: Are you serious.

8 RIC: Yes, ma'am, I'm not joking. ((King opens the car door))

When Richter made a request, King complied again:

9 RIC: ((As King gets back in car)) Can I see your driver's license you're being 10 stopped for speeding.

11 (.9) ((King reaches down and comes back up, presumably with her 12 license))

Both of these adjacency pairs demonstrate that King understood Richter's directives.

When King asked a question that challenged Richter's authority, he replied with an utterance that directly answered her question:

13 KIN: But I'm already stopped so technically can you stop me? (.1) Cuz you 14 didn't pull me over because I'm parked.

15 RIC: You only- ma'am you were about to go inside without a wallet, so I

16 know you were only coming here because you know I was coming to

17 pull you over.

18 KIN: Uh huh.

19 RIC: I can absolutely pull you over if you are already stopped, yes. Let me

20 see your driver's license.

21 KIN: ((King hands him the license))

King gave an agreement marker "Uh huh" (line 18) and handed the officer her license.

This traffic stop discourse seems routine so far in that the officer made requests,

instructed, and reinforced his authority when responding to King's question. In response, King complied with his order.

In lines 13 and 14 above, King challenged the legitimacy of the stop through questioning. This directive (line 13) suggests King was looking for clarification on the conditions under which Richter was entitled to assert his authority; even if his reasons for stopping her were valid, King suggested that the stop itself might not be - that Richter's window of opportunity for stopping her had passed. Kissine's (2013) formula, the reasons 
for B to bring about the truth of X may or may not be enough to cause B to actually bring about the truth of $\mathrm{X}$, is relevant here: King demonstrated her testing of the notion that Richter's reasons for stopping her might not be sufficient to make the actual stop legal and to cause her to agree to hand over her license. In other words, she questioned the extent of his authority under local conditions and therefore the legitimacy of the stop itself. That King accepted his directive in line 21 indicates that Richter's explanation was sufficient for King. Following Dorschel's (1989) formula, I assume whatever value or belief Richter claimed with his explanation (i.e. his institutional authority or knowledge about the local situation) King accepted as valid enough to fulfill the directive and give Richter the response he presumably was looking for.

Richter's next directive, however, seems to be rejected by King:

22 RIC: Take a seat back in the car so we can close the door.

23 ((King appears not to move))

24 RIC: Put your feet back in the car so I can close the door.

25 KIN: Could you please hurry up?

The differences between line 22 and line 24 are plentiful. In line 22, Richter issued an instruction and used the pronoun "we" to perhaps include King in the action. Richter also used the phrasing "take a seat", considered more polite than most imperatives. King's body looks as if it was seated and oriented toward the driver's side mirror with her feet on the ground with King looking at the officer, who was squarely facing her. Richter's order was for King to take a seat back in the car even though she was already sitting down in the driver's seat. It is unclear if King understood the directive, but her lack of movement or vocal response indicates she might have been either rejecting the order or reserving judgment. Richter rephrased his instruction as an order in line 24 by specifying that he 
wanted her to put her feet in the car. Richter specified the action, used the less polite "put your feet" instead of "take a seat," and replaced the pronoun "we" with "I." All of these modifications indicate the second attempt was more aggravated than the first.

This directive's adjacency pair was rejected; King did not put her feet in the car, and she asked Richter if he could "hurry up." The two non-acceptances could perhaps also indicate that King was not compelled by whatever reasons Richter had provided to expect her to fulfill his directives.

If King was questioning the conditions of the stop, she might also have been questioning Richter's authority to instruct her movements and positioning. His explanation for stopping her might not have extended to his authority to instruct her physically, and instead of questioning that authority as she had previously, her question deviated from the topic at hand to "Could you please hurry up" in line 24. This deviation might have prompted the subsequent struggle. Lawrence's (2004) assertion that issues arise when officers ask questions unrelated to the stated original reason for the stop could be applied here to the motorist instead. The two adjacency pairs constitute two dispreferred responses, one of which was off topic. For Richter, these responses might have signified two consecutive rejections to his orders and perhaps informed his next directive, which changed the nature of the stop.

When King did not make the gestural response Richter was looking for after ordering her to put her feet back in the car and when she asked if he could "hurry up," he simultaneously bent down to grab King while instructing her and tagging a request onto the end:

26 RIC: Okay, ma'am, stand up for me, okay? ((Richter bends down and reaches for 
This utterance is unusual in that in it Richter used "ma'am" for the first time simultaneously highlighting their social distance by using a politeness marker. However, that linguistic device was accompanied by Richer essentially performing three acts: an instruction with "Okay ma'am stand up for me," a request by tagging "okay" after it with upward intonation, and a threat by suddenly grabbing King. After this point in the encounter, King rarely responded to Richter's utterances, but mainly to his physicality and gestures.

Many of King's responses were clear reservations during which she either responded to the physical force rather than the locutionary force or she was not given a choice to comply. The following shows an example of both of these:

39 RIC: Get out of the car now.

40 ((Richter pulls King out of car and flips her to the other side of the

41 parking space and onto the ground))

42 KIN: Aw...

43 RIC: Put your hands behind your back!

44 KIN: Oh my -

45 RIC: Put your hands behind your back! You are under arrest.

46 KIN: Oh my God. Why are you doing this to me?

As line 39 was uttered, King clearly did not have a choice to comply or not, as she was physically made to do the action that the officer had ordered; her vocal reaction was probably to the physical force and not the order itself. In line 44, King was again probably responding to the physicality and not to the locution of the speech act. While the officer appears to have been physically restraining her on the ground, most of her utterances were exclamations of "Oh my god" and questioning "Why are you doing this to me?" but King's utterances that I coded as probably acknowledging Richter's orders imply she had 
already complied with his directive:

63 RIC: Put your hands behind your back!

64 KIN: That's what I was doing! Are you serious? God. Stop.

Rather than indicate a willingness to comply with an acceptance of "Yes sir," for example, the first utterance in line 64 indicates that an act of compliance had already occurred and that King believed the officer had missed it or was ignoring it. Arguably, this acknowledgement represents perhaps a forced compliance rather than one resulting from the obligation that might be expected from motorists being stopped. Of course, it might be unexpected that a stop for speeding becomes physical, and King expressed what can be interpreted as dismay in the second utterance of line 64 . While many of the utterances represent clear reservations, lines like 64 above and 53 below are coupled with rejections:

52 RIC: Put your hands behind your back!

53 KIN: Oh my God. Are you serious?

In line 53, King exclaimed again "Oh my god," and then followed it with another utterance that implies disbelief. The question "Are you serious" generally presupposes that the hearer cannot be serious. The implicature of this utterance is that King did not agree with the actions being taken and reserved her judgment about the order "Put your hands behind your back" possibly because she did not want to, felt she could not physically do it, or felt she had already complied.

In either case, the reasons for Richter's many directives might not have been shared or believed by King, which might be a clue as to why the encounter did not go smoothly. The categories of accepting, reserving judgment, or rejecting help to show how explicit those responses may or may not be. In the following sequence, King clearly 
reserved judgment in lines 12-13:

9 RIC: ((As King gets back in car)) Can I see your driver's license you're being 10 stopped for speeding.

11 (.9) ((King reaches down for something and comes back up))

12 KIN: But I'm already stopped so technically can you stop me? (.1) Cuz you

13 didn't pull me over because I'm parked.

14 RIC: You only- ma'am you were about to go inside without a wallet, so I

15 know you were only coming here because you know I was coming to

16 pull you over.

17 KIN: Um huh.

18 RIC: I can absolutely pull you over if you are already stopped, yes. Let me 19 see your driver's license.

20 KIN: ((King hands him the license))

When the officer asked to see King's license, King reserved judgment and questioned the legitimacy of Richter's request. This move can be interpreted as a questioning of Richter's reasons for making the request. If King did not share the value of the officer's authority, she may have believed his directive was not authorized. She clearly questioned his authority on a technicality specific to her particular situation (having pulled off the street and parked) and not necessarily in general. That is to say, the lack of congruity between beliefs shared by King and Richter might not be systemic, but rather contextual. Richter made clear in the next lines 14-15 and 18-19 how he perceived the context, thus defeasing the implications of King's question that Richter did not have the authority to stop her. In line 20, King accepted and handed over her license.

Again, this acceptance does not necessarily mean that King shared in the belief of Richter's authority, but that there was some compelling reason for her to accept it; the hearer does not have to actually share the beliefs or values the directive implies, only act as if they do (Dorschel, 1989). Presumably, Richter's utterances had something to do with convincing King of some legitimate reasons for fulfilling the directives; the two lines 14- 
15 logically argue the context, after which King uttered an agreement marker "uh-huh" 17. Then Richter continued to answer the question directly in line 18, using a degree marker "absolutely" and repeated his request as an order "Let me see your..." (18-19). The compelling reasons for King could potentially have been the re-contextualization, the repetition, or the advancement from request to order. Regardless, King accepted the directive.

At many times during the encounter, King rejected Richter's directives or reserved judgment with statements such as "Are you serious," an utterance which is not unmistakably clear in its meaning. Therefore, the officer would not know whether he had achieved his goal. Since a "hearer can understand without performing a speech act in response" (Dorschel, 1989, 325), uptake often requires explicit acceptance, reserving judgment, or rejection for the speaker to know their directive has been understood.

The power struggle in the encounter seems to be steeped in institutional expectations that the motorist complies with each of the officer's directives and the motorist's expectations to be able to exert agency at least as far as to question the officer's directives. A precedent seems to have been set for the latter in the encounter in lines 12-18 analyzed above. In those lines, King questioned the directive and Richter offered an answer and repeated his directive, to which King complied.

Escalation seems to have occurred quickly in line 24 "Could you please hurry up?" when King questioned the officer a second time with implications that 1) her time might be more important than the traffic stop and 2) Richter was moving slowly i.e. taking up too much of King's time. This utterance was accompanied by the action of not moving her feet into the vehicle, as had been requested. The combination of not fulfilling 
the directive and questioning the officer gave rise to what was surely an unexpected turn in the encounter: Richter's reach, which led to King's physical removal.

If the conditions of satisfaction for the speaker are that the action is fulfilled by the hearer, officer Richter rarely achieved that satisfaction. Most of King's responses did not fulfill the desired actions (mostly movements) that Richter was likely expecting. The directives went unfulfilled partially because King was most likely reacting to physical force, but also perhaps because she was being manipulated physically and unable to control her own movements. It is important to note that the utterance before the first physical gesture and subsequent escalation was a request that was met with the first refusal of the encounter - a nonverbal refusal of her failure to comply with Richter's request for King to put her feet in the car.

In his research on format tying, Goodwin (2006) discussed how participants refuse to provide sequentially relevant next actions. He contended that a first utterance or action is seen as providing a context for the next action. In other words, the first utterance sets up an expectation of what is to come next. This is especially true with the use of directives. In the King-Richter data, each participant refused to provide moves requested or ordered by the other. While Richter gave King clear orders, King's compliance in some cases seems to have been physically impossible:

59 ((Richter stands King up and kicks against her leg toward the ground.

60 Richter flips King back to the ground. King's arm buffers her fall))

61 RIC: Put your hands behind your back right now!

62 ((King's left leg is straight and right leg bent))

63 KIN: Stop. Will you let me get down, please.

64 RIC: Get down!

In line 61, while King was on the ground, Richter repeated for the seventh time, "Put 
your hands behind your back" adding an intensifier "now." His directive is clear, yet King responded with a directive of her own- "Stop" and a request to let her "get down" (63). In the video, King's left extended leg seems to be prohibiting her from lying on the ground, yet Richter seems to be pushing her toward the ground. Presumably, King requested Richter to allow her to move her leg so that she could lie on the ground. Richter then responded with the order "Get down" (64). Since at this point King was already on the ground, both of the participants probably wanted King to untangle her leg and lie flat on the ground. King's response indicates that she was unable to do so and was dependent upon Richter to allow her to carry out his directive, yet Richter's response indicates that he believed King should have been able to do this action on her own.

Whereas Richter's directive "Get down" appears to be both format tying to King's request by repeating her language and a refusal to provide the move requested by King, King's response "Stop" does not format tie. The second part of King's utterance in line 63 makes a request to Richter, but uses a different format than the imperative orders Richter had been using, as well as different lexical items. King's request uses an indirect speech act with "Will you let me..." and tags "please" onto the end of it. In the first utterance of line 69, again King did not format tie:

65 KIN: [...] Are you kidding me? Oh my god -

66 ((Richter has both of King's hands in one of his hands behind her back.

67 Reaches for cuffs.))

68 RIC: Put your hands behind your back!

69 KIN: That's what I was doing! ((Richter handcuffs King while she is on her 70 knees.)) Are you serious? God. Stop.

The format tying happened when King repeated her directive in imperative form with "Stop" (70) which seems to mirror the imperatives Richter used and represents how the 
two participants organized their argument. The word "stop" was repeated seven times in the encounter as an imperative, the first four times by Richter:

26 RIC: Get out of the- Stop resisting!

27 KIN: Oh my God.

28 RIC: Stop resisting!

29 KIN: Oh my God!

30 RIC: Stop resisting!

31 KIN: Ahh... [inaudible]

32 RIC: Stop resisting!

The format tying does not occur in adjacency pairs in this example, but rather later in lines (63) and (70). But in the excerpt below, the format tying does occur in an adjacency pair:

35 RIC: Get out of the car.

36 KIN: I'm getting out. Let me get out. Do not touch me.

Clearly King was trying to communicate to Richter, dropping the exclamations of the previous lines and adopting the format of directives with "Let me get out" and "Do not touch me," even orienting to and mirroring the language Richter had just used with "get out." The utterance constructed by Richter is countered by King. Her addition of "let me" is a precise orientation to the details of what was just said. In other words, Richter's own words are used to counter his order, implying that Richter is the one who needs to take action in order to fulfill the directive by permitting King the agency to exit the vehicle on her own.

Goodwin's research suggests that format tying such as this shapes how arguments unfold. In the lines below, King and Richter use more and similar directives:

37 RIC: ((Into his comm)) I need one at Wendy's.

38 KIN: Do not touch me.

39 RIC: Get out of the car now.

40 ((Richter pulls King out of car and flips her to the other side of the 41 parking space and onto the ground)) 
King repeated her previous directive (line 36 and 38), as did Richter, but tagging an amplifier "now" onto the end (line 35 and 39). These lines come immediately after the clear format tying that occurred in lines 35 and 36 . Rather than continue to format tie to each other's utterances, the participants appear to have been using repetition of their own utterances to organize the talk. Repetition to organize seems to be the case also in lines 50-57, when both participants repeated their own utterance for eight turns. King, however, made two modifications after each repetition:

$50 \quad$ RIC: Put your hands behind your back!

51 KIN: Oh God. Why are you doing this to me?

52 RIC: Put your hands behind your back!

53 KIN: ((indecipherable))

54 RIC: Put your hands behind your back!

55 KIN: Oh my God. Are you serious?

56 RIC: Put your hands behind your back!

57 KIN: ((Officer flips King)) Oh my God.

In the midst of "Oh god" and "Oh my god," two utterances counted as repetitions with one intensifier "my", King repeated a rejection from earlier and a question from earlier, one that had perhaps still received no answer. Regardless, this sequence does not provide resolution or countering.

The analysis of this case study revealed an escalation in types of directives used beginning with Richter's instructing and rising to questioning, stating, and finally ordering. The majority of Richter's directives were orders, one of which he repeated 8 times. It seems as though King understood most of the orders, but often rejected them on grounds that imply she either did not share in the belief that he had the authority to expect her to carry out the directives or was not able to physically carry out the directives.

The violence began after King did not carry out a directive to put her feet in the 
car and instead asked the officer if he could hurry up. It is difficult to know why King refused to provide a relevant next utterance to Richter's order, but it does show that King did not regard the order as one that needed to be carried out. The extreme physical reaction that Richter took was likely a surprise to King. During the physical altercation, Richter made few attempts to provide relevant next turns and used mostly repetition, thus intensifying to exchange. King, too, repeated many of her utterances, but also attempted to both ask questions and state that she was complying with Richter's orders. Many of King's exclamations seem to be responses not to Richter's utterance but rather to his physical gestures.

\section{Case 2: Bland-Encinia Data}

The second case study looks at an encounter between Sandra Bland, an African American woman on her way to a new job, and her arresting officer, Brian Encinia, who was an on-duty state trooper in Waller county, Texas, a fairly rural county northwest of Houston. (See Appendix B, Case Study 2 for the transcript analyzed here.) The dashcamera footage begins with Encinia finishing a citation for a different driver. He got back into his police vehicle and began driving. At an intersection, Bland's oncoming car passed Encinia's, and he promptly made a U-turn and began driving behind her. After about 30 seconds, he sped up behind her, Bland moved out of Encinia's lane to the right without using her turn signal, and Encinia put on his lights and pulled her over.

Encinia approached her vehicle on the passenger side, told her she was being stopped for failure to signal, and took her license back to his vehicle with him. After about eight-and-a-half minutes Encinia returned to Bland's vehicle. He asked her if she was okay, and Bland said no, describing the situation. Encinia asked her to put out the 
cigarette she was smoking, and Bland asked why she needed to. Smith's conclusions that motorists often exercise what agency they have seems relevant here. For Bland, this might have been part of her negotiation to maintain or even retrieve some of her power. Encinia then told her to step out of the vehicle. Bland said no, and verbal and physical struggle began with Bland in her vehicle and Encinia opening the driver's side door. Eventually Encinia leaned down to pull Bland out of the vehicle and ended up pulling out his Taser and threatening to use it, at which point Bland got out of her vehicle.

Encinia held his Taser on Bland as she exited and escorted her onto the sidewalk next to the police vehicle out of view of the dash-camera. No longer in view, the video provides audio of a physical struggle between Bland and Encinia during which we hear Bland cry out in pain, tell the officer he is about to break her wrist, and complain of her head being slammed into the ground. We also hear Encinia tell Bland that she would have received a warning if she hadn't started causing problems. Bland complained openly about his treatment of her, implied Encinia felt powerful treating a Black woman in this way, and began calling him profanities. Eventually a white female officer arrived and helped to restrain Bland and put her in the police vehicle.

This particular video went viral after Bland was found dead hanging in her jail cell three days later. Her death was ruled a suicide, which prompted multiple investigations into the incident and Bland's background. For six months before her death, Bland became active in the Black Lives Matter movement, making several posts and videos educating others about Black history and encouraging people to make friends across racial divides. The investigations also revealed friends' reports of depression. Some of this information might contribute to the broader context of racial tension in 
which this encounter occurred and was understood.

\section{Quantitative results.}

This conversation contained 106 utterances total, 42 of which were directives (40\%). Officer Encinia's utterances totaled 53, 37 of which were directives (70\%), and Sandra Bland's utterances totaled 52, seven of which were directives. Bland had 29 responses to Encinia's directives: 14 were rejecting, 11 were reserving judgment, and 7 were accepting. Encinia responded to Bland's directives with one acceptance and one rejection to her questions and one rejection to her warning/threat. As shown in Table 2, imperative/ordering made up most of Encinia's directives at $41 \%$, followed by almost half that amount of warning/threat at $24 \%$; questioning made up only $8 \%$, and instructing trailed behind at $3 \%$.

Table 2 - B-E Directives

Types of directives used number of times by Encinia and Bland as percentage of total directives in selected text.

\begin{tabular}{l|r|r}
\hline Type & \multicolumn{1}{|c|}{ Encinia } & \multicolumn{1}{|c}{ Bland } \\
\hline Ordering & $41 \%(\mathrm{n}=15)$ & $\mathrm{n}=1$ \\
\hline Warning & $24 \%(\mathrm{n}=9)$ & 0 \\
\hline Requesting & $19 \%(\mathrm{n}=7)$ & 0 \\
\hline Questioning & $8 \%(\mathrm{n}=3)$ & $\mathrm{n}=6$ \\
\hline Amplifieras directive & $5 \%(\mathrm{n}=2)$ & 0 \\
\hline Instructing & $3 \%(\mathrm{n}=1)$ & 0 \\
\hline TOTAL & $\mathrm{n}=37$ & $\mathrm{n}=7$
\end{tabular}

Note: Amplifiers as directive totaled 2, and both were

"now" used immediately after another order but set apart in timing and emphasis.

Noteworthy was that all of Bland's rejections came after imperative/ordering or warning/threat from Encinia with one exception: a response to Encinia's gestural grab for Bland (which I coded as a threat but did not count as an utterance); six out of nine reserving judgments came after imperative/ordering or warning/threat as well and the 
other three after either questioning or requesting; two of her acceptances came after questioning, and the final acceptance came after imperative/ordering, and, significantly, after Encinia drew his weapon.

\section{Qualitative discussion.}

Similar to the first case, Encinia also used a high number of imperative directives and Bland asked several questions, but the responses of each participant deviated from what might be expected. Many of Bland's responses were clear rejections where she stated explicitly "No" and followed with a statement of disbelieving Encinia's reasons for asking her to get out of the car:

29 ENC: Well you can step on out now.

30 BLA: I don't have to step out of my car.

31 ENC: Step out of the car.

32 BLA: Why am I- ((Encinia opens driver's side door))

33 ENC: Step out of the car $\uparrow$

34 BLA: No, no you don't have the right. No, you don't have the right.

These responses above illustrate clear understanding of the communicative act and suggest that Bland heard and understood the acts to be directives. That she demonstrated this understanding early on in the exchange provides evidence that she understood most of the similar directives that followed, particularly the imperative/ordering that reiterated "Step out of the car" (lines 3 and 5).

Bland's claim that the officer did not have the right to either force her out of her car or open her door suggests that she rejected the extent of the authority Encinia was claiming, which, in turn, suggests she assumed she knew the conditions under which Encinia would have thought he had convincing reasons to regard his imperative as valid or efficient and indeed to issue such imperatives in the first place. As discussed earlier, 
Kissine's (2013) formula is relevant to these data: the reasons for Bland to fulfill or accept the directive may not have been enough to cause her to accept the directive; in fact, she said as much. Dorschel's (1989) formula is also relevant: whatever value or belief Encinia claimed with his reasons (i.e. his institutional authority or domain over Bland in this situation) was not accepted by Bland. Under Dorschel's premise that even a rejection or lack of complying can be an act, in these data, Bland's disbelieving or rejecting of Encinia's reasons was the perlocutionary act in the example above.

Ultimately, the act demonstrated a hearing and understanding of Encinia's utterances as directives, which deems his communicative act successful from the perspective of communicating clearly his intentions. The argument here is that the understanding that a directive has been made is the criterion for success; even though conversations do not always go smoothly and participants do not always agree, it does not mean utterances were not understood.

The section of the exchange during which Bland exited the car demonstrates a different directive and response from that of the above. Below, Encinia drew his Taser and made a new threat, resulting in a different response from Bland:

63 BLA: So you're threatening to drag me out of my own car?

64 ENC: ((Draws Taser and points it at Bland)) Get out of the car!

65 BLA: And then you're going to-

66 ENC: I will light you up!

67 BLA: Wow. ((Bland exits car))

68 ENC: Get out! Now!

69 BLA: Wow. Wow.

The reasons Encinia gave through his directive became compelling for Bland in line 66 because she finally accepted the directive and carried out the action encoded in Encinia's directive. Encinia aggravated his threat from the "or else" structure to "I will 
light you up." If this further explanation of the consequences of failing to comply was believed or good enough for Bland, her response to exit the car makes sense. The new directive, however, was accompanied by Encinia's drawing of his Taser and pointing it at Bland; with this gesture came a reason, as well, whether it reinforced the utterance or vice versa: The drawn Taser functioned as a reason, and Bland accepted it. Either the new threat or the drawn Taser or both possibly gave Bland the new understanding of the directive that Encinia's threats were not idle and that he was likely ready to carry out the action threatened. Clearly Bland recognized both the utterance and the gesture as a directive, understood both, and found the reasons compelling enough to accept through a gesture of her own: exiting the car. Again, the communicative act was a success for Encinia.

This final acceptance is significant; there were few acceptances in this segment of data, and most of the ordering was met with rejection. A chart of pairings between directive type and response category shows this higher proportion of rejections to orders. Distribution of imperatives and threats was across all three response categories, as Figure 2 shows; however, the highest numbers corresponded to rejecting. 


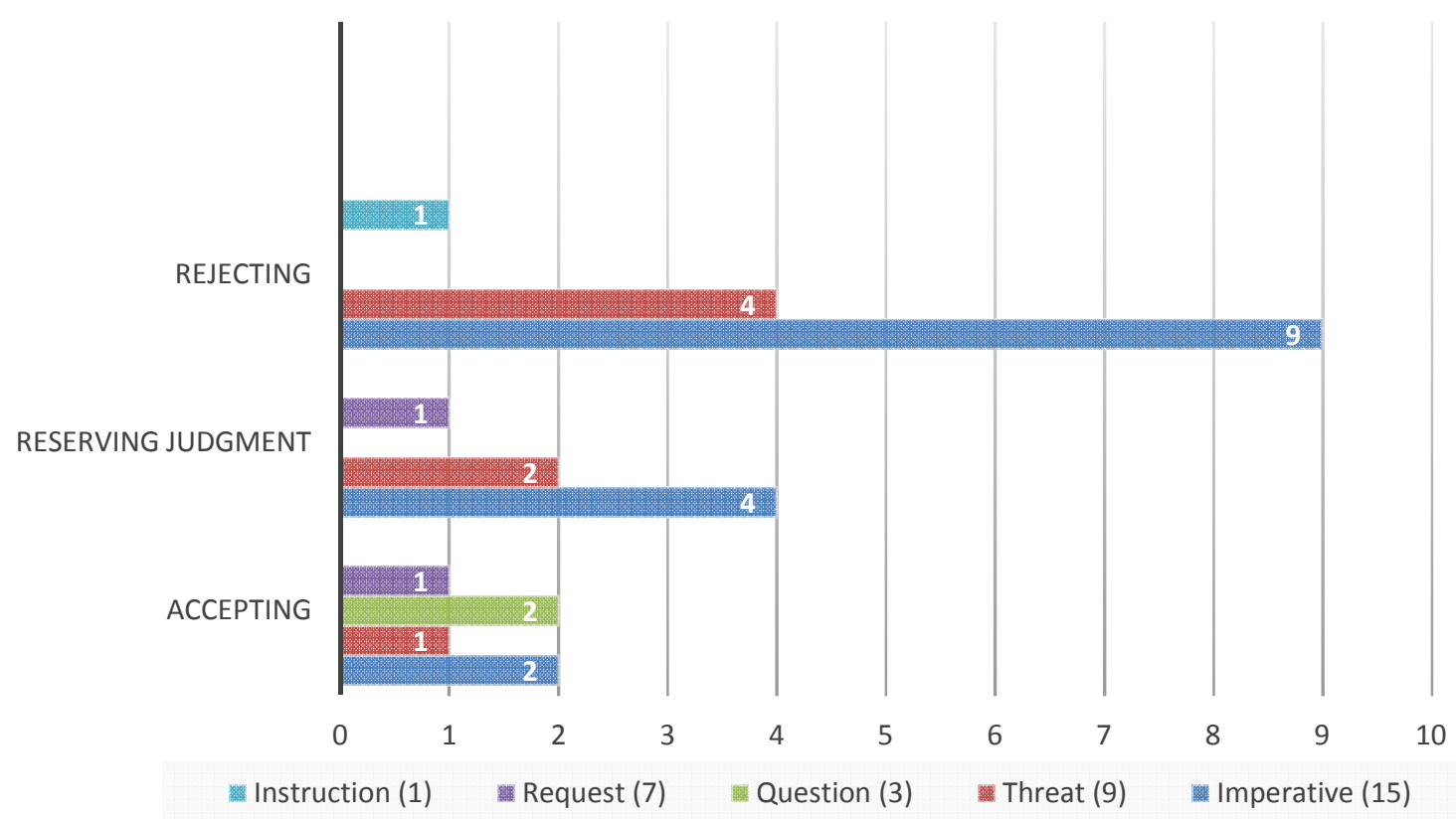

Figure 2: Number of directives by Encinia per type across response category. Chart includes total number of uses per type of directive by Encinia.

Throughout the exchange Encinia added types of directives, presumably in an attempt to help him achieve the responses he wanted. But most of his acts of ordering remained the same (ex. "Step out of the car"), which elicited similar responses each time. Repetition is not considered the same utterance (i.e. each utterance is counted separately even if it repeats the same words) and therefore might not be taken in the same manner each time it occurs. The repetition between Encinia and Bland may signify an escalation that tested how far each participant would go before either complying or trying a new tactic. I would speculate that if there had been more variation of linguistic features within the types of directives, the response categories might have changed, as well. Kissine's (2013) notion of reasons suggests that what was being said to Bland in each directive represented a set of values, claims, beliefs, attitudes, and that those were not compelling to her in that context, for the most part. When looking at Figure 2 it is clear the only 
questions used by Encinia received a response of acceptance. The relationship between the acceptance and the reasons for those questions, the perlocution, was framed in a way that Bland shared, agreed with, or believed. Generally, these data show implications of violent threat as compelling reasons between police and motorists and resistance to those reasons.

The fact that Bland mostly accepted or rejected Encinia's directives supports that she did acknowledge and understand the conditions under which Encinia would have convincing reasons to regard his directives as either valid or efficient. That Bland accepted some of the directives in the beginning of the conversation demonstrates that she might also have thought of the conditions as being valid or efficient, at least to a certain degree. Evidently, she did acknowledge and even commented on those conditions when she said "This is your job. I'm waitin' on you” (line 18), implying that he had a job to do that was sanctioned institutionally and that she was at the will of Encinia doing that job. Bland was not disobedient at that point in the conversation, which might be reflective of her acceptance of the conditions up to that point or of her acceptance of the type of directives used up to that point.

I found format tying began early on in the encounter and immediately precipitated the struggle to get Bland out of the vehicle:

23 ENC: Are you done?

24 BLA: You asked me what was wrong, now I told you.

25 ENC: Okay.

26 BLA: So now I'm done, yeah.

27 ENC: You mind putting out your cigarette, please? If you don't mind?

In line 23, Encinia might have been implying that Bland's previous utterance was taking too long or that he was unsure if she had more to say. After giving an explanation in line 
24 Bland emphasized the explanation in line 26 by adding the adverb of time "now" and tagging the format tie "done" with an affirmative "yeah." Two lines later Encinia instructed "Well you can step on out now" and Bland mirrored the language and used "step out" to respond:

29 ENC: Well you can step on out now.

30 BLA: I don't have to step out of my car.

Encinia continued to use this phrasing throughout the struggle, setting a structure for how the argument was organized. Furthermore, Bland format tied periodically with the latter phrase and others:

52 ENC: Get out of the car!

53 BLA: Don't touch me. Don't touch me! I'm not under arrest — you don't

54 have the right to take me out of the car.

55 ENC: You are under arrest!

56 BLA: I'm under arrest?

In lines 53 and 54, Bland clearly tied her idea of specific parameters to the syntactic frame of "out of the car," negating the implied conditions that the officer had institutional authority to remove her. She also used the active verb "take me," presumably referring to Encinia's reach for her physically, orienting to the context of force she perceived. Bland's specifying that Encinia was trying to "take" her out of the car coupled with her direct refusal "You don't have the right" transforms the argument from a local context to a greater context about authority and autonomy. Moving the argument from one realm into another might also escalate the argument.

It is important to point out that Bland's utterances might have provided opportunities for Encinia to state reasons other than his authority. Particularly, many of her questions went unanswered. For instance, when Encinia asked Bland to put her 
cigarette out, and she responded, Encinia missed an opportunity to give alternative reasons or even reframe the reasons already given:

29 ENC: You mind putting out your cigarette, please? If you don't mind?

30 BLA: I'm in my car, why do I have to put out my cigarette?

31 ENC: Well you can step on out now.

Encinia did not provide a relevant next turn in the sequence topic. Instead, it appears that he continued to use his authority as reasons for Bland to carry out his directives-reasons that Bland clearly had reservations about or rejected from the beginning of the interaction.

While format tying appears to set the directive organization for much of the argument, it also appears to mirror the contextual struggle between the two participants as they vie to assert what each thinks is within their authoritative realm. One of the premises of format tying is essentially using a previous utterance to build upon, thus "one-upping" the other participant. The other premise has to do with providing sequentially relevant next actions, or rather the refusal to provide that. If both participants are format tying, often they are refusing to provide relevant next actions, presuming the next action should progress the conversation. When directives are involved, we would expect a subsequent preferred next action to be fulfilling the directive, whether that means answering a question, or fulfilling an order.

To summarize the analysis, case study 2 revealed that all of the rejections that Bland gave were in response to Encinia's ordering and threatening and not to other directives such as questioning or instructing. Encinia used more ordering than any other directive, which of course gave rise to more rejecting than any other response. Bland also made clear rejections to Encinia's authority, demonstrating that she did not share in the value of his authoritative position to the extent that he did. For the most part, Bland 
demonstrated that she did not believe in the reasons Encinia gave for her to carry out his directives, but some analysis revealed that perhaps Encinia did not make clear his reasons. Whether or not Encinia intended to draw the weapon well before he actually did, Bland demonstrated that she was compelled to carry out his directives only after he drew his weapon. That is to say, at least one of Encinia's reasons for expecting Bland to carry out his order was his Taser, even if he did not have it drawn the entire time.

Repetition also showed up in this analysis (see Appendix A). Encinia gave several similar orders, each time resulting in similar rejections. The orders vary in intensifiers, including tone, markers such as "now", reformatting by moving from simple orders to "or else" structure, and lexical choice (i.e. "Step out of the car" vs. "Get out of the car"). Repetition also manifested in format tying. Several times Bland used Encinia's structure to counter his directives. In this case study, however, it did appear that format tying always led to a refusal to supply a relevant next turn. In fact, many of Bland's format tying was direct and to the point. 


\section{Chapter 5}

\section{Conclusion}

My initial questions were 1) what kind of directives were used, 2) how were they responded to, 3) how did the directives contribute to escalation, and 4) how might power and authority have played a role. Ultimately, I sought to discover at least a partial explanation as to why these encounters unfolded they way they did. The dominant factors that indicated escalation were the repetition of directives given by the officers and the rejections to those directives. The data revealed that most of the directives the participants used were orders, and most of those orders were repetitions. The officers' directives were either compelling or not, meaning they either persuaded the motorists to fulfill them or not. The answers to the remainder of the questions seem to lie in why those directives were either compelling or not, what the difference was between the successful and unsuccessful ones, and mostly hinge on reasons and the values behind them.

Overall, directives that were repeated did not seem to be compelling. In both cases, most of King's and Bland's rejections were made in response to orders as opposed to other directive types, but particularly in King's case. The analysis of case study 2 demonstrated that Bland heard and understood Encinia's directives during their traffic stop, that his communicative acts were successful from the perspective of conveying his intentions, and that language represented reasons behind Encinia's directives that, for the most part, did not compel Bland to accept and carry out the actions. The analysis also made clear that Bland did not share in many of Encinia's beliefs that stood for reasons to fulfill his directives. The compelling directive in this encounter was the threat of physical force with a Taser. Using a weapon as reason for Bland to carry out the order was more 
persuasive than appealing to her belief in Encinia's authority. Bland, however, continued to profess disbelief in Enicinia's moral authority even while following his orders after the use of the Taser. This indicates a conflict that might be greater in scope than just this encounter or this study.

In case study 1, directives were repeated and escalated in a fairly systematic way; officer Richter's less intense directives at the beginning (requests and instructing) provided some reasons for King to comply, which might have persuaded King to both understand the truth conditions of Richter's utterances and the premise that formed the basis of his authority and power. It seems that exercising his authority as reason was compelling to a certain extent, especially after King asked a direct question and Richter directly answered it. But using authoritative reasons was not always compelling, and certainly not after using physical force. Unlike officer Encinia, Richter did not use a weapon, and his use of physical force did not produce an action in King that satisfied Richter. In case study 1, it seemed unproductive for the officer to continue using tactics that were not producing the results he wanted, a conclusion that could perhaps be generalized across cases similar to this one.

The analysis implies that if traffic police want their interactions to go smoothly when they stop a motorist, they not only need to employ careful language to elicit the actions they want, but also they need to employ language that represents reasons that can be shared, believed, or agreed upon by the motorist. It is likely that traffic police and some motorists at traffic stops do not share a value system, and it would therefore be difficult for the officers to have their expectations for acceptance met. As seen in these data, however, traffic police do have a variety of linguistic devices they can employ to 
seek to convince the motorist of their reasons.

In both cases, escalation occurred most rapidly immediately after the points at which one of the participants made a request or asked about something seemingly outside the scope of the reason for the stop. If traffic stops are expected to go a certain way and the officer sets the justification for the stop, then the officer's deviation from that justification generally gives rise to issues (cf. Lawrence, 2004). In case 1, the officer asked the motorist to put her feet back in the car so that he could close the door, which might have been taken by King as a deviation and non-standard. When King replied asking if the officer could hurry up, Richter might have taken the utterance as too far a deviation from standard traffic stop interactions. In case 2, Encinia asked Bland to put her cigarette out, which might have seemed like too much of a deviation from the justification of her stop. It is important to note, as well, that Bland expressed frustration and doubt in the justification given to her for her stop, so it is plausible that any further deviation might ring disingenuous. The problematic nature of these cases can be seen at many points throughout the interaction, but escalation was most apparent immediately after directives that seemed unrelated to the stated original justification for the traffic stop.

Relevant to these data, Goodwin's research suggests that format tying shapes how arguments unfold and how directives might contribute to escalation. I conclude that these kind of countered utterances, when coupled with directives, also escalated the conversation in both cases in this study. When considering the sequence of what speech acts the officers in these data used, the analysis shows that the motorists responded more favorably when the officers used fewer orders and fewer repetitions, but not when they used orders in conjunction with physical force unless using a weapon. In both cases, the 
switch from making requests, statements, and instruction to ordering happened in tandem with physical force. Perhaps if traffic police used a variety of speech acts to get what they want, they should also consider what kind of force to pair with a given speech act. There might be a variety of linguistic resources to use with a variety of physical tactics. If officers use the same speech act half a dozen times with no desired result, perhaps they could or should try other speech acts.

The data show that continual format tying leads to refusals to provide sequentially relevant responses. In the data above, this format tying is reflected in repetition that, on the part of the officers, leads to refusals to answer questions or respond to cries for help from the motorists. I argue that both Bland and King were looking to engage in a free exchange (cf. Shon, 2005) in their interactions, particularly when expressing a desire to understand the situation. Several times they used constatives and asked questions, challenging the authority of the officer. The data suggest that the motorists were operating as if they were in an interaction and not a transaction, as Shon (2005) described police officers usually perceive the case to be. As Storey (1995) contended, a major feature of threats is the power or authority to carry them out, but if the hearer does not believe the speaker has or should have that power or authority, as Bland and King professed, one might argue that power is diminished to some degree.

The presence of authority in both of these cases was invoked by each of the participants, and the power at play was most evident in the officers' expressions that they had the authority to make the directives they were giving. That is to say, they believed they had the law on their side. These expressions were most evident in the reasons implicit behind their directives. 
Dorschel's (1989) argument that speech acts act as reasons in the situation in which they are uttered helps to shed light on the data analyzed in this thesis: even though the officers used a variety of directives, they did not make clear to the motorists through their speech that they were offering a variety of reasons, even after the motorists rejected those reasons. For example, it might be that officer Encinia's reasons for Bland to get out of the car changed from authoritative (using his position as a representative of an institution) to forcible (using his ability to draw his Taser at any time) without expressing those reasons to her before the Taser was actually drawn. The officers' lack of variety in reason-giving coupled with their variety in directives used presents compelling evidence that an explicit distinction should be made between what is being directed and reasons for what is being directed. The officers' high use of directives puts them in the position of power to wield authority while also withholding their reasons. Following this logic, it might be prudent for traffic police to use speech acts other than or in addition to directives to help convey their reasons for taking the actions they take or expecting the actions they demand.

In addition, I can conclude that physical force is not always in itself a compelling reason to fulfill a directive for motorists such as these, especially in light of the current climate of outrage over police brutality. Since the Black Lives Matter movement, most Black Americans are aware that the consequences of resisting authority-as-reasons might be made public, might be reviewed, and might have new implications for holding police accountable for the seemingly disproportionate violent encounters between them. In this era, perhaps Black Americans no longer accept the reasons given them in settings such as these and a new re-contextualization is needed. I would also argue that the burden lies 
with the police to make concrete that re-contextualization and to work towards making these encounters go smoothly. They do, indeed, have the institutional authority and power to make those changes and direct the encounters so that they are safe for everyone.

A shared value system often contributes to harmony in general, and there are implications here that suggest that either harmony needs to be found in ways other than a shared value system or a system needs to be put in place that both police and citizens can agree on. Successful communication presupposes at least some degree of shared values. Perhaps a more explicit training system can be developed, not only for police but also for citizens; if there are rules to the game of traffic stops, citizens need to be made aware of them and their limits, or, better yet, agree to those rules.

Given the results of this study, it appears that the way escalation to violence unfolds might signify a struggle of not only language and power but also intersectionality of gender and race between the participants which warrants a discussion outside the scope of this thesis. If Bland continued to express disbelief in Encinia's authority while carrying out orders, then other factors might be implicated in the dynamics between Black Americans, women, and police. My hope is that this study can provide a jumping off point for studies that focus more on sociology and can build on the implications this linguistic analysis begins. 


\section{References}

Ainsworth, J. (2008). You have the right to remain silent...but only if you ask for it just so: The role of linguistic ideology in American police interrogation law. International Journal of Speech, Language \& The Law, 15(1), 1-21. doi:10.1558/ijsll.v15i1.1

Bach, K. (1998). Speech acts. In C. Edward (Ed.), Routledge encyclopedia of philosophy (pp. 385-390). London: Routledge.

Berk-Seligson, S. (2009). Coerced confession: The discourse of bilingual police interrogations. Berlin/Boston, DE: De Gruyter Mouton. Retrieved from http://www.ebrary.com

Blalock, G., DeVaro, J., Leventhal, S., \& Simon, D. (2011). Gender bias in power relationships: Evidence from police traffic stops. Applied Economics, 43(29), 4469-4485. doi: 10.1080/00036846.2010.49146

Boggs, S. (1978). The development of verbal disputing in part-Hawaiian children. Language in Society. 7(3), 325-344. doi:10.1017/S0047404500005753 Brenneis,

D. \& Lein, L. (1977). "You fruithead": A sociolinguistic approach to children's dispute settlement. In S. Ervin-Tripp \& C. Mitchell-Kernan (Eds.), Child discourse (pp.49-65). New York: Academic Press.

Capehart, J. (2015, August 05). How lack of “discretion” killed DuBose, Bland. Miami Times, pp. 2A.

Carroll, L., \& Gonzalez, M. (n.d.). Out of place. Journal of Research in Crime and Delinquency, 51(5), 559-584. DOI:10.1177/0022427814523788

Childers, S. (2012). Discrimination during traffic stops: How an economic account 
justifying racial profiling fall short. New York University Law Review, 87(4), 1025-1059.

Danet, B., Hoffman, K.B. \& Kermish, N.C. (1980). Threats to the life of the president: An analysis of linguistic issues, Journal of Media Law and Practice 1(2), 180-90.

Dorschel, A. (1989). What is it to understand a directive speech act? Australasian Journal of Philosophy, 67(3), 319-340. doi.org/10.1080/00048408912350161

Engel, R., Tillyer, R., Klahm IV, C., \& Frank, J. (2012). From the officer's perspective: A multilevel examination of citizens' demeanor during traffic stops. Justice Quarterly, 29(5), 650-683. DOI: 10.1080/07418825.2011.574643

Epp, C., Maynard-Moody, S., \& Haider-Markel, D. P. (2014). Pulled over: How police stops define race and citizenship. Chicago: The University of Chicago Press. Farrell, A. (n.d.). Explaining leniency. Crime \& Delinquency, 61(4), 509-537. DOI:10.1177/0011128711420108

Goffman, E. (1981). Forms of talk. Philadelphia: University of Pennsylvania Press.

Goodwin, C. (2006). Retrospective and prospective orientation in the construction of argumentative moves. Text \& Talk, 26(4), 443-461.

Goodwin, C., \& Goodwin, M.H. (1992). Assessments and the construction of contexts. In A. Duranti \& C. Goodwin (Eds.), Rethinking context (pp. 147-189). Cambridge: Cambridge University Press. Retrieved from http://www.sscnet.ucla.edu/anthro/faculty/goodwin/Assessments_and_Constructi on_of_Context.pdf

Goodwin, M. \& Goodwin, C. (1987). Children's arguing. In S. Philips, S. Steele \& C. Tanz (Eds.), Language, gender, and sex in comparative perspective (pp. 200- 
248). Cambridge: Cambridge University Press.

Grice, P. (2001). Aspects of reason. Oxford, GB: Clarendon Press. Retrieved from http://www.ebrary.com

Grimshaw, A. (1990). Conflict talk: Sociolinguistic investigations of arguments in conversations. Cambridge; New York: Cambridge University Press.

Haley, J. (2016). Speech acts at traffic stops. Unpublished paper, Portland State University.

Kissine, M. (2013). From utterances to speech acts. Cambridge: Cambridge University Press. Retrieved from http://www.eblib.com

LaFave, W. (2004). The "routine traffic stop" from start to finish: Too much "routine," not enough fourth amendment. Michigan Law Review, 102(8), 1843-1905.

Lawrence, B. (2003, September). The scope of police questioning during a routine traffic stop: Do questions outside the scope of the original justification for the stop create impermissible seizures if they do not prolong the stop? Fordham Urban Law Journal, 30(6), 1919-1948. Retrieved from http://law.fordham.edu/publications/index.ihtml?pubid=400

Lorenzo-Dus, N. (2008). Real disorder in the court: An investigation of conflict talk in US television courtroom shows. Media, Culture \& Society, 30(1), 81-107. doi: $10.1177 / 0163443708088613$

Martinez-Flor, A. (2010). Suggestions: How social norms affect pragmatic behavior. In A. Martinez-Flor \& E. Uso-Juan (Eds.), Speech act performance: Theoretical, empirical and methodological issues (pp. 257-274). Amsterdam/Philadelphia: John Benjamins Publishing Company. 
Maschler, Y., \& Nir, B. (2014). Complementation in linear and dialogic syntax: The case of Hebrew divergently aligned discourse. Cognitive Linguistics, 25(3), 523-557. doi:10.1515/cog-2014-0029

Mason, M. (2016). The "preparatory" and "argumentation” stages of police interrogation: A linguistic analysis of a criminal investigation. Language and Communication, $48,79-87$.

Matoesian, G. (2005). Nailing down an answer: Participations of power in trial talk. Discourse Studies, 7(6), 733-59. Retrieved from http://dis.sagepub.com.proxy.lib.pdx.edu/content/7/6/733.full.pdf + html

Nissi, R. (2013). Decrypting the text: The construction and function of disagreement in Bible study sessions. Text \& Talk, 33(6), 771-791. doi:10.1515/text-2013-0033

O'Keefe, D. (1977). Two concepts of argument. Journal of the American Forensic Association, 13(3), 121-128. Retrieved from http://ill.lib.pdx.edu/PDF/418760.pdf

Rojek, J., Rosenfeld, R., \& Decker, S. (2012). Policing race: The racial stratification of searches in police traffic stops. Criminology, 50, 993. DOI: 10.1111/j.17459125.2012.00285.x

Scott, S. (2002). Linguistic feature variation within disagreements: An empirical investigation. Text, 22(2), 301. DOI: 10.1515/text.2002.011

Searle, J. R. (1976). A classification of illocutionary acts. Language in Society. 5(1), 123. Retrieved from http://www.jstor.org.proxy.lib.pdx.edu/stable/4166848

Shon, P. \& Chong H. (2005). "I'd grab the S-O-B by his hair and yank him out the window": The fraternal order of warnings and threats in police-citizen encounters. Discourse \& Society, 16(6), 829-45. 
Smith, W. (2010). Footing, resistance and control: Negotiating a traffic citation. Critical Inquiry in Language Studies, 7(2-3), 173-186. DOI:

$10.1080 / 15427581003757475$

Stivers, T. (2013). Sequence organization. In J. Sidnell \& T. Stivers (Eds.), The handbook of conversation analysis (pp. 191-209). Chichester, UK: Wiley-Blackwell; xvii. doi: 10.1002/9781118325001.ch10

Stygall, G. (2008). “Did they really say that?”: The women of Wenatchee: Vulnerability, confessions, and linguistic analysis. Journal of English Linguistics. 36(3), 220238. DOI: $10.1177 / 0075424208321140$

Whitehead, J. (2015, July 30). "Comply or die": Drivers beware of costly, deadly dangers of traffic stops. Mississippi Link, p. 14. 


\section{Appendix A}

\section{Tables with Examples}

Table A1

Types of directives used number of times by Richter and King as percentage of total directives.

Type

\begin{tabular}{|c|c|c|c|}
\hline Ordering & $79 \%(n=23)$ & $22 \%(n=5)$ & $\begin{array}{l}\text { Let me see your driver's license. (18) } \\
\text { Put your feet back in the car so I can close } \\
\text { the door. (23) } \\
\text { Get out of the-Stop resisting! (27) Stop } \\
\text { resisting! (29) } \\
\text { Stop resisting! (31) } \\
\text { Stop resisting! } \\
\text { (33) Get out of } \\
\text { the car. (36) } \\
\text { Get out of the car now. (40) } \\
\text { Put your hands behind your } \\
\text { back! (43) Put your hands } \\
\text { behind your back! (45) Put } \\
\text { your hands behind your back! } \\
\text { (48) Put your hands behind } \\
\text { your back! (50) Put your hands } \\
\text { behind your back! (52) Put } \\
\text { your hands behind your back! } \\
\text { (54) } \\
\text { Put your hands behind your back right } \\
\text { now! (59) Get down! (61) } \\
\text { Put your hands behind your } \\
\text { back! (64) Don't stand up. }\end{array}$ \\
\hline Instructing & $14 \%(n=4)$ & 0 & $\begin{array}{l}\text { Ma'am take a seat back in the car } \\
\text { please. (1) Take a seat back in your } \\
\text { vehicle please. (3) } \\
\text { Take a seat back in the car so we can close } \\
\text { the door. (21) }\end{array}$ \\
\hline Warning & $3 \%(n=1)$ & 0 & I'm about to Tase you. (56) \\
\hline Requesting & $3 \%(n=1)$ & 0 & Can I see your driver's license... (9) \\
\hline Questioning & 0 & $77 \%(n=17)$ & \\
\hline TOTAL & 29 & 22 & \\
\hline
\end{tabular}


Table A2

Types of directives used number of times by Encinia and Bland as percentage of total directives.

\begin{tabular}{|c|c|c|c|}
\hline Туре & Encinia & Bland & Encinia's directives \\
\hline Ordering & $41 \%(n=15)$ & $n=1$ & $\begin{array}{l}\text { Step out of the car. (32) Step out of the car! } \\
\text { (34) Step out of the car. (36) Step out... (38) } \\
\text { Step out... (40) } \\
\text { Step out... (42) } \\
\text { Get out of the car } \\
\text { now. (42) Get out! } \\
\text { (47) } \\
\text { Get out of the } \\
\text { car! (53) Get } \\
\text { out of the car! } \\
\text { (58) Get out } \\
\text { of the car. } \\
\text { (59) } \\
\text { I said get out of the } \\
\text { car! (61) Get out of } \\
\text { the car! (65) } \\
\text { Get out! (69) }\end{array}$ \\
\hline Warning & $19 \%(n=7)$ & 0 & $\begin{array}{l}\text {...or I will remove you (38) } \\
\text {...or I will remove you. (40) } \\
\text {...or I will remove you. (42) } \\
\text {...or I'm going to remove } \\
\text { you. (43) I'm going to yank } \\
\text { you out of here.(45) I'm } \\
\text { going to drag you out of }\end{array}$ \\
\hline Requesting & $19 \%(n=7)$ & 0 & $\begin{array}{l}\text { Do you have your driver's license and } \\
\text { registration with you?(3) } \\
\text { How long have you been in } \\
\text { Texas. (6) Do you have a } \\
\text { driver's license? (8) Where } \\
\text { you headed to now? (12) } \\
\text { You mind putting out your cigarette, please? If }\end{array}$ \\
\hline Questioning & $8 \%(n=3)$ & $\mathrm{n}=6$ & $\begin{array}{l}\text { What's wrong?(4) You } \\
\text { OK? (17) Are you }\end{array}$ \\
\hline $\begin{array}{l}\text { Amplifier as } \\
\text { directive }\end{array}$ & $5 \%(n=2)$ & 0 & $\begin{array}{l}\text { Now! (69) } \\
\text { Now. (71) }\end{array}$ \\
\hline Instructing & $3 \%(n=1)$ & 0 & Well you can step on out now. (30) \\
\hline TOTAL & $\mathrm{n}=37$ & $\mathrm{n}=7$ & \\
\hline
\end{tabular}

Note: Amplifiers as directive totaled 2, and both were "now" used immediately after another order but set apart in timing and emphasis. 


\section{Appendix B}

\section{Transcripts of Data}

This appendix contains transcripts of the segments of data analyzed in this paper. The first is a transcript of Case-Study 1. The second is a transcript of Case-Study 2. Before each transcript is the reference citation for the data and a summary of how the interaction begins.

Case-Study 1:

PoliceActivity. (2016, July 21). Police Dashcam Video Shows Violent Arrest of Austin School Teacher Breaion King [video file]. Retrieved from https://www.youtube.com/watch?v=Z3sMpfm59hc

King was parked in an outdoor parking lot. The dashcamera of the police vehicle was behind King's car, perpendicular and facing left. King exited her vehicle as Richter exited the police vehicle and began speaking. He was about 20 feet away from her when began his approach.

1 RIC: Ma'am take a seat back in the car please.

$2 \quad$ KIN: I'm sorry?

3 RIC: Take a seat back in your vehicle please.

$4 \quad$ KIN: [inaudible] ((points to something past the officer))

5 RIC: Okay ma'am you're being pulled over right now so I need you to take a seat

6 back in your car.

$7 \quad$ KIN: Are you serious?

8 RIC: Yes, ma'am, I'm not joking. ((King opens the door)) ((As she gets back in 
driver's license you're being stopped for speeding. ((King reaches down for something and comes back up))

13 KIN: But I'm already stopped so technically can you stop me? (.1) Cuz you didn't pull me over because I'm parked.

15 RIC: You only- ma'am you were about to go inside without a wallet, so I know

16 you were only coming here because you know I was coming to pull you

17 over.

18 KIN: Uh huh.

19 RIC: I can absolutely pull you over if you are already stopped, yes. Let me see 20 your driver's license.

21 KIN: ((King hands him the license))

22 RIC: Take a seat back in the car so we can close the door.

$23 \quad(($ King appears not to move her feet) $)$

24 Put your feet back in the car so I can close the door.

25 KIN: Could you please hurry up?

26 RIC: Okay, ma'am, stand up for me, okay? ((Richter bends down and reaches in

$27 \quad$ car))

28 KIN: No, why are you grabbing me? 
29 RIC: Get out of the- Stop resisting!

30 KIN: Oh my God.

31 RIC: Stop resisting!

32 KIN: Oh my God!

33 RIC: Stop resisting!

34 KIN: Ahh... [inaudible]

35 RIC: Stop resisting!

$36 \quad$ ((Horn Sounds))

37 KIN: I'm not- ((Richter stands back up))

38 RIC: Get out of the car.

39 KIN: I'm getting out. Let me get out. Do not touch me.

40 RIC: ((Into the radio)) I need one at Wendy's.

$41 \quad$ KIN: Do not touch me.

42 RIC: Get out of the car now. ((Richter pulls King out of car and flips her to the

43 other side of the parking space and onto the ground))

44 KIN: Aw:

45 RIC: Put your hands behind your back!

$46 \quad$ KIN: Oh my-

47 RIC: ((Richter's hands on Kings hands in front of her)) Put your hands behind

48 your back! You are under arrest.

49 KIN: Oh my God. Why are you doing this to me? 
50 RIC: Put your hands behind your back!

51 KIN: Oh God. Why are you doing this to me?

52 RIC: Put your hands behind your back!

53 KIN: [inaudible]

54 RIC: Put your hands behind your back!

$55 \quad$ KIN: Oh my God. Are you serious?

56 RIC: Put your hands behind your back!

57 KIN: ((Officer flips King)) Oh my God.

58 RIC: I'm about to Tase you.

59 ((Richter stands King up and kicks against King's leg toward the ground.

60 Richter flips King back to the ground. King's arm buffers her fall))

61 RIC: Put your hands behind your back right now!

62 KIN: ((King's left leg is straight and right leg bent)) Stop. Will you let me get,

63 down please.

64 RIC: Get down!

65 KIN: Are you kidding me? Oh my god- ((Richter has both of King's hands in one

66 of his hands behind her back. Reaches for cuffs))

67 RIC: Put your hands behind your back!

68 KIN: That's what I was doing! ((Richter handcuffs King while she is on her

69 knees.)) Are you serious? God. Stop. 
70 RIC: Don't. Stand. Up.

71 KIN: I'm not trying to stand up. I'm trying to put my hands behind my back. God

72 damn. Are you serious. Are you kidding me?

73 RIC: Quit moving your hands.

$74 \quad$ KIN: So you can put them back? That's all. Are you kidding me?

75 RIC: Get up.

$76 \quad$ ((Officer 2 Arrives $))$

77 KIN: Ow! Look at him. He's treating me like shit. I didn't do anything.

78 OF2: Spread your feet.

79 KIN: What are you doing? I need a black police.

80 RIC: Walk. 
Case-Study 2:

Texas Department of Public Safety. (2015, July 22). Sandra Bland traffic stop [video file]. Retrieved from https://www.youtube.com/watch? $\mathrm{v}=\mathrm{CaW} 09 \mathrm{Ymr} 2 \mathrm{BA}$ My analysis began at 2:18 when the officer pulled Bland over and the vehicles stopped. Encinia approached the Bland's passenger side window a few seconds later. The transcript begins at 2:40.

1 ENC: Hello ma'am. We're the Texas Highway Patrol and the reason for your stop

2 is because you failed to signal the lane change. Do you have your driver's

$3 \quad$ license and registration with you? (1.5) What's wrong?

$4 \quad$ BLA: [inaudible] (5.0)

$5 \quad$ ENC: How long have you been in Texas?

6 BLA: Got here just yesterday.

$7 \quad$ ENC: OK. (.8) Do you have a driver's license?

$8 \quad$ BLA: Didn't I give you my driver's license?

9 ENC: No, Ma'am.

10 BLA: [inaudible]

11 ENC: OK, where you headed to now?

12 BLA: [inaudible]

13 ENC: Give me a few minutes, alright.

14 BLA: Alright.

15 3:59 ((Encinia returns to his car for several minutes, then approaches Bland 16 again.))

17 ENC: 8:39 OK, ma'am. ((Pause.)) You OK? 
18 BLA: I'm waiting on you. This is your job. I'm waiting on you. When're you

$19 \quad$ going to let me go?

20 ENC: I don't know, you seem very really irritated.

21 BLA: I am. I really am. I feel like it's crap what I'm getting a ticket for. I was

22 getting out of your way. You were speeding up, tailing me, so I move over

23 and you stop me. So yeah, I am a little irritated, but that doesn't stop you

24 from giving me a ticket, so [inaudible] ticket.

25 ENC: Are you done?

26 BLA: You asked me what was wrong, now I told you.

27 ENC: OK.

28 BLA: So now I'm done, yeah. (.8)

29 ENC: You mind putting out your cigarette, please? If you don't mind?

30 BLA: I'm in my car, why do I have to put out my cigarette?

31 ENC: Well you can step on out now.

32 BLA: I don't have to step out of my car.

33 ENC: Step out of the car. (.7)

34 BLA: Why am I- ((Encinia opens driver's side door))

35 ENC: Step out of the car!

36 BLA: No, no you don't have the right. No, you don't have the right.

37 ENC: Step out of the car.

38 BLA: You do not have the right. You do not have the right to do that.

39 ENC: I do have the right, now step out or I will remove you.

40 BLA: I refuse to talk to you other than to identify myself. 
41 ENC: Step out or I will remove you.

42 BLA: I am getting removed for a failure to signal?

43 ENC: Step out or I will remove you. I'm giving you a lawful order. (1.0) Get out

44 of the car now or I'm going to remove you.

45 BLA: And I'm calling my lawyer.

46 ENC: I'm going to yank you out of here. ((Encinia reaches inside the car.))

47 BLA: OK, you're going to yank me out of my car?

48 ENC: Get out!

49 BLA: OK, alright.

50 ENC: ((calling in backup)) 2547.

51 BLA: Let's do this.

52 ENC: Yeah, we're going to. ((Encinia grabs for Bland.))

53 BLA: Don't touch me!

54 ENC: Get out of the car!

55 BLA: Don't touch me. Don't touch me! I'm not under arrest — you don't have the 56 right to take me out of the car.

57 ENC: You are under arrest!

58 BLA: I'm under arrest? For what? For what? For what?

59 ENC: ((To dispatch)) 2547 county fm 1098 [inaudible] send me another unit.

$60 \quad(($ To Bland $))$ Get out of the car! Get out of the car now!

61 BLA: Why am I being apprehended? You're trying to give me a ticket for failure-

62 ENC: I said get out of the car!

63 BLA: Why am I being apprehended? You just opened my - 
64 ENC: I'm giving you a lawful order. I'm going to drag you out of here.

65 BLA: So you're threatening to drag me out of my own car?

66 ENC: ((Encinia draws Taser and points it at Bland)) Get out of the car!

67 BLA: And then you're going to-

68 ENC: I will light you up!

69 BLA: Wow. ((Bland exits car.))

70 ENC: Get out! Now!

71 BLA: Wow. Wow.

72 ENC: Get out. Now. Get out of the car!

73 BLA: For a failure to signal? You're doing all of this for a failure to signal?

74 ENC: Get over there. 